\title{
The GREENROOF module (v7.3) for modelling green roof hydrological and energetic performances within TEB
}

\author{
C. S. de Munck ${ }^{1}$, A. Lemonsu ${ }^{1}$, R. Bouzouidja ${ }^{2,3,4}$, V. Masson $^{1}$, and R. Claverie ${ }^{3}$ \\ ${ }^{1}$ Météo France, CNRM-GAME, CNRS UMR3589, Centre National de Recherches Météorologiques, Toulouse, France \\ ${ }^{2}$ NIDAPLAST, Thiant, France \\ ${ }^{3}$ Centre d'Études Techniques de l'Équipement de l'Est, Tomblaine, France \\ ${ }^{4}$ Université de Lorraine, LEMTA UMR7563, Vandœuvre-les-Nancy, France
}

Correspondence to: C. S. de Munck (cecile.demunck@meteo.fr)

Received: 21 December 2012 - Published in Geosci. Model Dev. Discuss.: 20 February 2013

Revised: 13 September 2013 - Accepted: 17 September 2013 - Published: 8 November 2013

\begin{abstract}
The need to prepare cities for climate change adaptation requests the urban modeller community to implement sustainable adaptation strategies within their models to be tested against specific city morphologies and scenarios. Greening city roofs is part of these strategies. In this context, the GREENROOF module for TEB (town energy balance) has been developed to model the interactions between buildings and green roof systems at the scale of the city. This module, which combines the ISBA model (Interaction between Soil Biosphere and Atmosphere) and TEB, allows for one to describe an extensive green roof composed of four functional layers (vegetation - grasses or sedums; substrate; retention/drainage layers; and artificial roof layers) and to model vegetation-atmosphere fluxes of heat, water and momentum, as well as the hydrological fluxes throughout the substrate and the drainage layers, and the thermal fluxes throughout the natural and artificial layers of the green roof. TEB-GREENROOF (SURFEX v7.3) should therefore be able to represent the impact of climate forcings on the functioning of green roof vegetation and, conversely, the influence of the green roof on the local climate. An evaluation of GREENROOF is performed for a case study located in Nancy (France) which consists of an instrumented extensive green roof with sedums and substrate and drainage layers that are typical of this kind of construction. After calibration of the drainage layer hydrological characteristics, model results show good dynamics for the substrate water content and the drainage at the green roof base, with nevertheless a tendency to underestimate the water content and overestimate the drainage. This does not impact too much the green
\end{abstract}

roof temperatures, which present a good agreement with observations. Nonetheless GREENROOF tends to overestimate the soil temperatures and their amplitudes, but this effect is less important in the drainage layer. These results are encouraging with regard to modelling the impact of green roofs on thermal indoor comfort and energy consumption at the scale of cities, for which GREENROOF will be running with the building energy version of TEB - TEB-BEM. Moreover, with the green roof studied for GREENROOF evaluation being a type of extensive green roof widespread in cities, the type of hydrological characteristics highlighted for the case study will be used as the standard configuration to model extensive green roof impacts at the scale of cities.

\section{Introduction}

In the literature, green roofs (roofs with a vegetated surface and a growing medium have been credited with a large number of environmental benefits. Many experiments conducted on green roofs have highlighted their potential to reduce roof runoff entering the storm water systems through retention and evapotranspiration. This has been demonstrated at the site scale (Berghage et al., 2009 and Voyde et al., 2010, are two good examples) as well as at the city (Mentens et al., 2006) and landscape (Oberndorfer et al., 2007) scales. Reduced roof runoff also implies reduced rain water pollutants entering storm water systems (Berndtsson et al., 2009), although this benefit may slightly be counterbalanced by the additional source of pollution represented by the green roof 
substrates themselves (Oberndorfer et al., 2007). Considering energy aspects, green roofs have the ability to moderate temperature changes within buildings (Castleton et al., 2010), with beneficial consequences on building energy consumption (Getter and Rowe, 2006; Castleton et al., 2010; Jacquet, 2011) due to increased thermal mass, shading and evaporative cooling (compared to standard roofs). As for energy savings, it may vary with the season and green roof design (materials and thicknesses), although it seems strongly influenced by the level of insulation of the structural roof (Jaffal et al., 2012). Jacquet (2011) observed for a green roof plot in Montréal a reduction in air conditioning demand in summer of 98.9 and $90.8 \%$ (respective of when the green roof was irrigated and not) and a milder reduction in heating demand in winter (38.3 and $27.4 \%$, depending again on irrigation). All this site-based evidence for green roof benefits has now contributed to promoting the use of city-scale green roof infrastructure as a sustainable adaptation strategy for climate change (Bass and Baskaran, 2003; EEA, 2012; Foster at al., 2011; Giguère, 2009; Lawlor et al., 2006; Penney, 2008; USEPA, 2008). The implementation of green roofs as opposed to urban forests and street trees may represent a more realistic and efficient greening strategy at the heart of cities, where the building fraction is high (and the ground-base surface available for greening scarce) and the initial evapotranspiration potential low.

The need for taking this research from the building scale to that of the city is clear, especially in the light of climate change. A modelling approach is the only realistic way an adaptation strategy such as roof greening can be evaluated citywide and for various seasons or long time series, hence the need for green roof models.

So far, very few studies have attempted to quantify the potential of green roof infrastructures at city scale. Three such studies were found, but these do not represent green roofs (nor buildings) explicitly. In these studies, building roofs are replaced by natural evaporating surfaces (grass, ground level), and energy and hydrological transfers are simulated with very simple parameterizations and calibrations. Bass et al. (2003) attempted to quantify the potential of green roofs for urban heat island (UHI) mitigation using this kind of modelling approach. They simulated the greening of $50 \%$ of the available roof surfaces throughout the city of Toronto (by replacing roof surfaces with grass), and predicted a mild cooling over part of the city of the order of $0.5^{\circ} \mathrm{C}$ without irrigation, and a greater and spatially wider cooling $\left(2{ }^{\circ} \mathrm{C}\right)$ with irrigation of the "green roofs" and the ground-level grass of the densest areas of Toronto. Gill et al. (2007) compared the impact of green roofs on surface temperatures (based on a simple energy balance equation) and runoff (via a standard runoff curve number approach) for various urban morphology classes (UMC) for the conurbation of Greater Manchester in the UK. They showed that "greening" all roofs made the most significant contribution to maximum surface temperature and runoff reduction in the most urbanized UMCs (respectively $6.6^{\circ} \mathrm{C}$ and $17.6 \%$ for the town centre). Following the approach of Bass et al. (2003), Rosenzweig et al. (2009) suggested that a "green roof" infrastructure for New York City could reduce urban air temperatures by $1.4^{\circ} \mathrm{C}$ on average and $3.2^{\circ} \mathrm{C}$ at best, which may lead to a reduction in UHI amplitude.

More detailed models are needed for city-scale applications that can explicitly describe green roofs and the thermal and hydrological behaviours associated with them, so that their impacts in terms of building energetics, comfort, UHI and runoff can be more accurately evaluated. With this aim, a detailed green roof model should be integrated into an urban canopy model in order to be run under imposed (present or future) climatic conditions or coupled to a meteorological model. This way the environmental benefits highlighted at the building scale could be studied and quantified more widely, more accurately and under various climatic constraints.

In order to set up a strategy for implementing green roofs within our town energy balance (TEB) urban canopy model (Masson, 2000; Hamdi and Masson, 2008), a review of the types of green roof implemented in cities nowadays was primarily undertaken (Sect. 2). This allowed for us to determine the main design and functions that a green roof model should describe, and consequently the physical processes associated that need to be captured. There followed a review of green roof modelling studies to establish an inventory of existing green roof models, with regard to both their complexity and their research objectives. On these bases, a green roof parameterization has been developed for TEB. The implementation of this GREENROOF module was part of a wider effort to implement various types of urban vegetation within the model TEB (Lemonsu et al., 2012). The hypothesis and the parameterization of GREENROOF are presented (Sect. 3). Then GREENROOF is run for an instrumented extensive green roof plot in the northeast of France (Sect. 4). Within Sect. 4, prior to the actual evaluation, a calibration exercise is undertaken and presented in order to determine the hydrological behaviour (and the associated hydrological properties) of the experimental plot drainage layer. Indeed, through this case study we aim to establish from which soil type the standard materials which form green roof drainage layers are closest to in terms of their hydrological behaviour. Evaluation results are presented both with regard to the hydrological and thermal performances of the green roof.

\section{Strategy for modelling green roofs within TEB}

\subsection{Generic design of a green roof and physical processes associated}

Green roofs of two types can be found in cities. Those called "rooftop gardens" support fairly large shrubs or trees. Due to the intensive care needed at implantation and management, 
they are commonly called "intensive green roofs", and are generally implemented for recreational use. Those containing only one or two low-profile plant species, and therefore requiring a minimal growing medium, are called "extensive". They are often used for improved thermal and hydrological performances (Wark and Wark, 2003), and are thus interesting to model as an adaptation strategy.

Based on the technical and scientific literature (Wark and Wark, 2003; Lazzarin et al., 2005), a generic design for extensive green roofs can be reached. From top to bottom, the essential components are a layer of vegetation; a layer of soil-forming material called substrate, which is the growing medium for the vegetation; a different soil-forming-material layer which helps to control the moisture status of the overlaying substrate (drainage or retention function depending on the plant species/climate association); and a mandatory waterproofing sheet to prevent water damage to the structural roof. Therefore, the final green roof design can be considered as the superposition of a "natural" compartment (vegetation and different soil-forming-material layers) and of an artificial compartment (waterproof and structural roof materials).

In addition, experimental studies on pilot green roofs (for example Bass and Baskaran, 2003; Berghage et al., 2009; Jacquet, 2011; Jim and He, 2010; Jim 2011; Jim and Peng, 2011; Nardini et al., 2012) have highlighted heat and water transfers within these "natural" layers which are similar to those which establish themselves within ground-level natural surfaces except for specific limit conditions. The transfers involved in a natural surface, be it at ground or roof level, are energetic, thermal and hydrological. The energy balance results in the balance between the surface net radiation and the latent, sensible and storage heat fluxes. Heat conduction and storage occur and can be strongly influenced by soil moisture content. But unlike open ground natural surfaces, for green roof natural surfaces, the heat gains or losses from the thermal contact with the bearing roof should be considered. In terms of hydrological transfers, a green roof surface behaves like any other natural surface (vertical water fluxes depend on soil moisture gradients, drainage occurs if super-saturated conditions appear and surface runoff may establish during rainfall events) except that the hydrological characteristics of green roof soil-forming materials are very different from those of natural soils, and that the water drained out of a green roof base is lost "in favour of" the rainwater network. These differences do not change the nature of the transfers involved, but act rather as boundary conditions for these transfers.

Therefore, it seems realistic to make the hypothesis that the natural layers of green roofs could be simulated by a standard soil-vegetation model incorporating the boundary conditions presented and, i.e. the finite dimension of the green roof and the presence of a structural built roof at its base.

\subsection{The state of the art in green roof modelling}

The current state of the art in green roof models highlights two modelling topics: that of the energy performance, and that of the hydrological performance; the modelling of both is rarely combined. The simple thermal and hydrological approaches are not presented here because they do not meet the criteria defined in the objectives presented.

All the detailed models of heat transfer (Alexandri and Jones, 2007; Del Barrio, 1998; Kumar and Kaushik, 2005; Ouldboukhitine et al., 2011; Sailor, 2008 - also known as the Ecoroof module for EnergyPlus) have in common an explicit description of green roofs, which takes into account a structural roof model, a soil model and a canopy model. While the energy balance at the green roof surface is performed in a more or less complex way (especially with regard to modelling the behaviour of the vegetation), the heat transfer is subsequently simulated by all these models based on a standard conduction equation. As far as modelling vegetation behaviour is concerned, all models parameterize vegetation transpiration as a function of the meteorological conditions and the gaseous equilibrium which establishes between the outside and the inside of the plant (via the plant stomatal resistance) - except that of Ouldboukhitine et al. (2011), which uses a simpler formulation (Penman-Monteith). Although these models account for the hydrological status of the green roof, it is with the sole purpose of computing soil effective thermal characteristics (as in function of soil moisture). Soil moisture status is either measured or estimated via a simple or a mixed form of Richards equation, but hydrological performance is generally not evaluated.

Most of the studies aimed at modelling the hydrology of green roofs (Hilten et al., 2008; Palla et al., 2009, 2012) have used the HYDRUS software (Simunek et al., 1994, 2005), whose most recent version also takes into account the heat transfer (Yu and Zheng, 2010). This calibrated model relies on the Richards equation and on the hydraulic functions of Van Genuchten (1980) and Mualem (1976) to simulate the processes of infiltration, lateral flow and surface runoff and predict moisture content profiles. Although very detailed, this model needs user-input evapotranspiration rates, which must therefore be estimated by other means. For numerical reasons (finite element method), HYDRUS works at very fine spatial resolutions. The work of Palla et al. (1999) is a good example of this resolution: they used 3695 grid elements to simulate a roof of $215 \mathrm{~cm}$ long by $46 \mathrm{~cm}$ thick. Consequently, a model such as HYDRUS is used to evaluate the hydrological performance of individual green roofs at small temporal scales such as a hydrological event (generally a few hours), but its computing cost due to its fine spatial resolution is not appropriate for city-scale applications.

In summary, even if most models are able to capture the dominant processes involved in green roof soil and structural compartments, none of them currently couple a combined modelling of thermal and hydrological processes that could 
be used on the scale of a city and for long time periods. The presence and impact of drainage or retention layers are also not simulated, even though these layers play a major role, not only with regard to hydrological performance but also in terms of thermal performance, as evidenced in the work of Jim and Tsang (2011). Finally, the difficulty encountered by all models remains the calibration, as is the case for all models with these levels of complexity.

\subsection{Strategy for the inclusion of green roofs within TEB}

As established previously, the heat and water transfers involved in the natural layers of green roofs (atmosphere, vegetation, and substrate and hydrological control layers) are similar to those of perfectly natural surfaces. They can therefore be simulated, as is the case in the models previously examined, by a standard soil and vegetation model, provided that it is calibrated to reflect the peculiar characteristics of the soilforming materials used for the construction of green roofs. Therefore, the strategy proposed and ultimately retained for the inclusion of green roofs within TEB is to use a soil and vegetation model that can not only be calibrated for a specific soil but would also have the ability to overcome the limitations of existing models. The ideal model should allow for a coupled modelling of green roof hydrological and energetic performances, employ sufficiently detailed parameterizations to describe the physical processes involved (including evapotranspiration and soil water flows), and at the same time have spatial resolutions (i.e. time calculations) suitable for modelling applications at city scale.

\section{A green roof module for TEB}

\subsection{Current modelling of the urban climate with TEB}

Urban climate modelling at the National Centre for Meteorological Research (CNRM-GAME) of Météo France relies on the use of the SURFEX land surface modelling system (Masson et al., 2013). It characterizes a study area based on four land use types (urban, natural, freshwater, and sea and ocean surfaces), and computes the exchange of heat, water and momentum between each type of surface and the atmosphere. More specifically, SURFEX features TEB (Masson, 2000) for solely urban surfaces and the ISBA model (Interaction between Soil Biosphere and Atmosphere) developed by Noilhan and Planton (1989) for natural and agricultural surfaces.

For TEB, the urban landscape is simplified as a network of street canyons of infinite length. Within each surface resolved by the model (also called mesh), it is possible to specify the geometric, radiative and thermal characteristics of an average street canyon represented (for equiprobable street orientations) or to fix these features street canyon by street canyon (for different street directions). TEB simulates the exchange of heat and water for three generic surfaces (roof, wall and road) and computes the urban microclimate variables at street level, as well as energy and water budgets from the neighbourhood to the city scale (Lemonsu et al., 2004, 2010; Offerle et al., 2005; Pigeon et al., 2008) and the feedback on the meteorological variables, when it is coupled to an atmospheric model (de Munck et al., 2013; Lemonsu and Masson, 2002). Recently, to better describe the finer scale interactions between artificial surfaces and natural surfaces found within cities, the ISBA model used for natural and agricultural surfaces has been integrated within TEB (resulting in the TEB-Veg configuration) and evaluated by Lemonsu et al. (2012). Given the modelling strategy retained and the aim to optimize source code development while retaining the modular structure of the SURFEX tool, an approach similar to Lemonsu et al. (2012), relying on ISBA, was considered well adapted and detailed enough to characterize and simulate water, energy and momentum fluxes within the natural layers of green roofs.

\subsection{Using ISBA-DF coupled with TEB for modelling green roofs}

Beyond being part of the SURFEX platform and being used in the weather forecast model of Météo France, the advantages of ISBA are numerous: since 1989, the year of its initial formulation by Noilhan and Planton (1989), it has been constantly enriched with detailed representations of physical processes (including surface atmosphere processes and hydrological and thermal transfers within the soil) as well as evaluated (Masson et al., 2013). Using ISBA for the natural layers of roofs makes it possible to have a model that offers a good compromise in terms of accuracy and computational costs for local- to global-scale applications, while allowing for the opportunity to benefit from various other options (e.g. carbon sequestration) and future improvements.

\subsubsection{Estimation of evapotranspiration}

Whatever the version, ISBA uses a detailed parameterization for the estimation of evapotranspiration, which is an essential component of green roof water balance. The transfer of heat and water between the atmosphere, the vegetation and the soil compartments of the green roofs is simulated through surface fluxes (Fig. 1), which are connected to each other through the latent heat flux (LE), which is the sum of the plant transpiration $\left(\mathrm{LE}_{\mathrm{TR}}\right)$, the soil evaporation $\left(\mathrm{LE}_{\mathrm{G}}\right)$, and the evaporation of the water intercepted by plant foliage $\left(L E_{V}\right)$. These fluxes are estimated by detailed parameterizations, especially plant transpiration $\left(\mathrm{LE}_{\mathrm{TR}}\right)$, which is, in the ISBA standard version, estimated as follows:

$\mathrm{LE}_{\mathrm{TR}}=F_{\mathrm{veg}} \rho_{\mathrm{a}} C_{H} V_{\mathrm{a}} H_{\mathrm{V}}(\mathrm{VPD})$,

where $F_{\text {veg }}$ is the fraction of vegetation covering the ground; $\rho_{\mathrm{a}}$ the air density; $C_{H}$ the turbulent exchange coefficient; $V_{\mathrm{a}}$ the wind speed; and $H_{\mathrm{V}}$ and VPD respectively the Halstead 


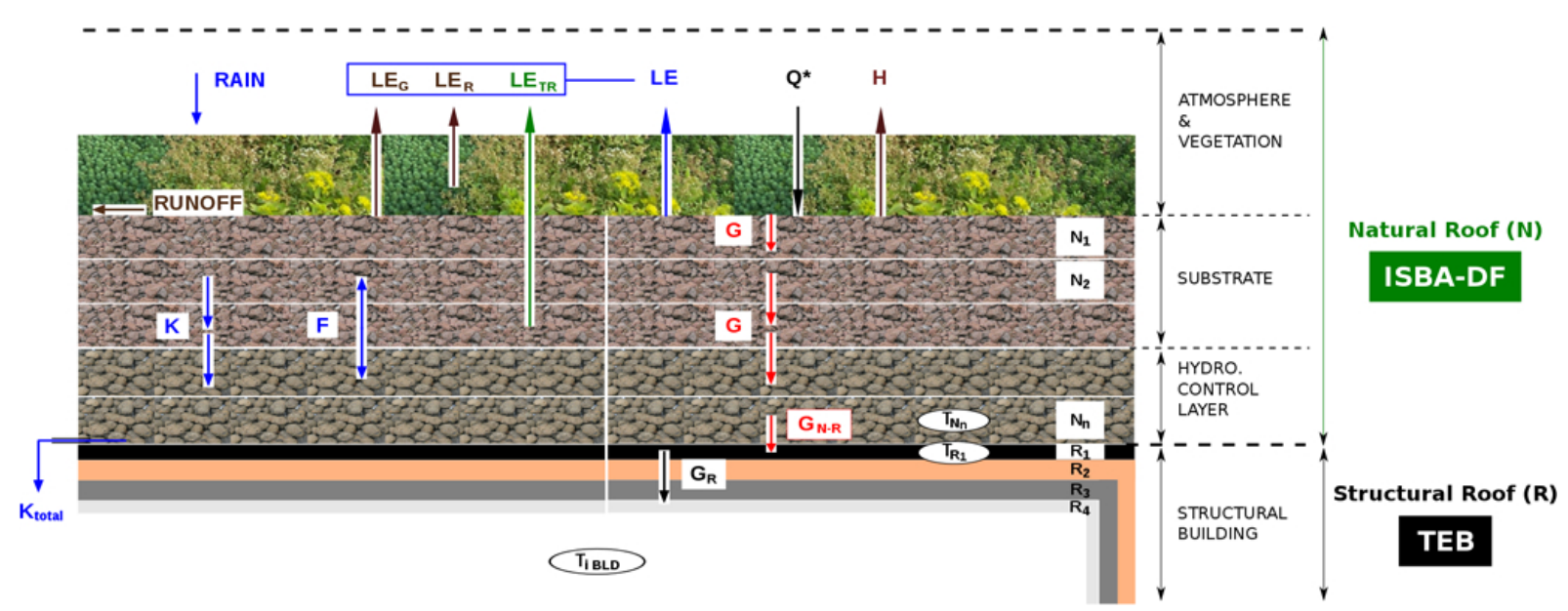

Fig. 1. Green roof design for TEB-GREENROOF and associated physical processes. Left: hydrological processes - surface runoff (RUNOFF), vertical water fluxes ( $F$, infiltration or upward capillary action depending on moisture gradient), supersaturated drainage $(K)$ and water drained out of the green roof base water $\left(K_{\text {total }}\right)$ and precipitation (RAIN) Right: energy balance terms - net radiation $\left(Q^{*}\right)$, sensible heat flux $(H)$, latent heat flux (LE) and ground storage heat flux $(G)$. LE is the sum of the ground evaporation (LE $\mathrm{G}_{\mathrm{G}}$ ), the evaporation of the water intercepted by the plant canopy $\left(\mathrm{LE}_{R}\right)$ and the vegetation transpiration (LETR). Top: thermal processes - within all layers, thermal conduction ( $G$ between natural layers, $G_{R}$ between artificial layers, with $Q_{N-R}$ the heat flux coupling the natural and structural roofs.

coefficient and the vapour pressure deficit in the air, which are calculated as follows:

$$
\begin{aligned}
H_{\mathrm{V}} & =\frac{R_{\mathrm{a}}+\delta_{h} R_{\mathrm{S}}}{R_{\mathrm{a}}+R_{\mathrm{S}}}, \\
\mathrm{VPD} & =q_{\mathrm{sat}}\left(T_{\mathrm{S}}\right)-q_{\mathrm{a}} .
\end{aligned}
$$

VPD is calculated in Eq. (3) as the difference between the humidity of the air at saturation $q_{\mathrm{sat}}\left(T_{\mathrm{S}}\right)$ and the actual air humidity $q_{\mathrm{a}}$ around the plants. In Eq. (2), $\delta_{h}$ represents the fraction of foliage covered by intercepted rainwater, $R_{\mathrm{a}}$ the aerodynamic resistance and $R_{\mathrm{S}}$ the stomatal resistance. The latter is derived within ISBA from the formulation of Jarvis (1976):

$R_{\mathrm{S}}=\frac{R_{\mathrm{S} \min }}{\mathrm{LAI}} \frac{F_{1}}{F_{2} F_{3} F_{4}}$

where $R_{\text {Smin }}$ represents the minimum stomatal resistance of the vegetation, LAI its leaf area index, and the $F$ factors' functions describe the influence of the environment $\left(F_{1}, F_{3}\right.$ and $\left.F_{4}\right)$ or the soil hydrological status $\left(F_{2}\right)$ on the stomatal resistance. $F_{1}$ describes the effect of the photosynthetic active radiation (PAR), and $F_{3}$ and $F_{4}$ the respective influence of the temperature and the VPD on evapotranspiration. For a for a detailed description of these factor formulations, see Boone (2000).

\subsubsection{Modelling of hydrological and thermal transfers in the soil}

Given the different nature and role of the soil compartments of green roofs (substrate and drainage or/and retention layers), it is interesting to use ISBA for its explicit multilayer version ISBA-DF, developed by Boone et al. (2000). Because it allows for us to represent the vertical heterogeneity of a soil (in terms of its hydrological and thermal properties but also in terms of its root distribution), ISBA-DF has the potential to accurately simulate different hydrological behaviours for a substrate and drainage/retention layers, which appears to be an improvement compared to existing green roof models.

On the hydrological side, ISBA-DF is capable of predicting green roof surface runoff that may occur in response to extreme rainfall events (Fig. 1). Inside the substrate and the hydrological control layers, ISBA-DF simulates the water fluxes due to vertical moisture gradients $(F)$ and the water vertical drainage $(K)$ that establishes when these layers exceed supersaturation. This way, the overall water discharge from the green roof (which is frequently recorded) can be estimated by combining the contributions of the total drainage out of the green roof base $\left(K_{\text {total }}\right)$ and the surface runoff.

The soil hydrology is based on a mixed form of the Richards equation to describe the transfer of water through the soil through Darcy's law (changes in moisture and water potential) when transfers of heat (conduction) are described by a classical Fourier law. The coupling between heat and water transfers is finally realized through effective soil thermal characteristics, which evolve in time with the soil moisture status. The effective thermal capacity of the soil is calculated as the weighting of the heat capacity of water and the heat capacity of the dry soil matrix following Peters-Lidard et al. (1998). Similarly, the effective thermal conductivity of the soil is estimated according to Farouki (1986) as a function of the water content, the soil porosity and the conductivity of the dry soil. This corresponds to the level of detail encountered in the most detailed green roof models (Alexandri and 
Atm ospheric forcing above the canopy: Temperature, Humidity. Wind, Incoming radiation

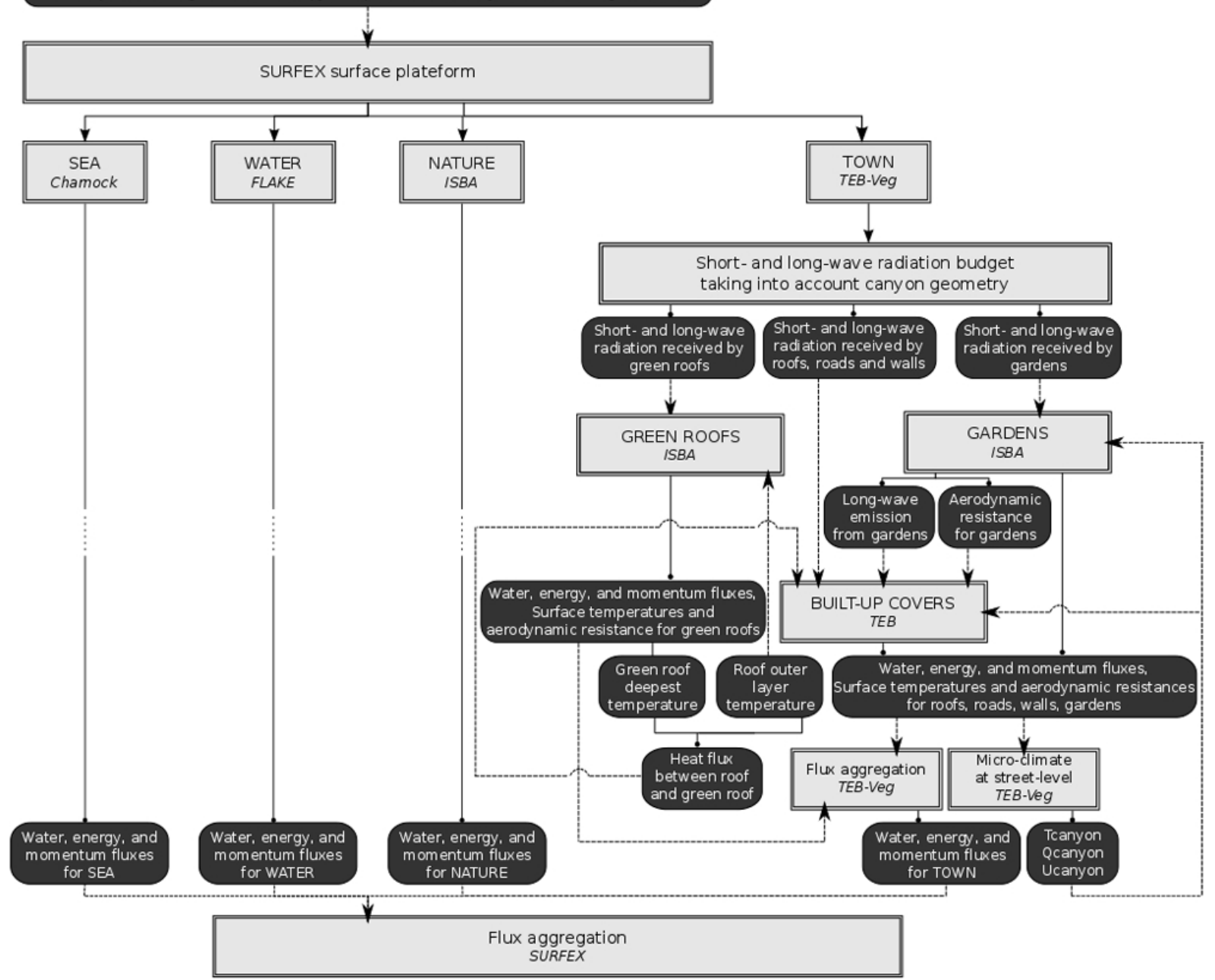

Fig. 2. Source code organization of GREENROOF within TEB-Veg and SURFEX.

Jones, 2007; Del Barrio, 1998; Sailor, 2008). In ISBA-DF, all the soil intrinsic characteristics, be they thermal or hydrological, are estimated based on a set of pedotransfer functions and prognostic equations described in Boone et al. (2000) and Decharme et al. (2011).

The added value of the ISBA-DF version with regard to evapotranspiration comes from a better calculation of the $F_{2}$ factor (Eq. 4). Indeed, contrary to the standard version of ISBA, which estimates a uniform stress factor for the entire column of soil, ISBA-DF uses the vertical profiles for root distribution and water content to compute a vertical distribution for $F_{2}$ :

$F_{2}(j)=\frac{w(j)-w_{\text {wilt }}(j)}{w_{\mathrm{fc}}(j)-w_{\text {wilt }}(j)}$,

where $w_{\text {wilt }}(j)$ and $w_{\mathrm{fc}}(j)$ are respectively the water contents at wilting point and field capacity of the layer $j$ of soil. Using ISBA-DF for green roof natural layers allows for us to specify a root distribution profile only within the substrate layers (and not beyond within the drainage or retention layers).

This constitutes a good level of detail considering the spatial scale aimed at, and should assist in accurately simulating the energy balance at the surface of the green roof, and consequently the heat conduction $(G)$ into the substrate and the layers beyond, which is essential to ensure a good prediction of heat transfers within the entire green roof system.

\subsubsection{Coupling ISBA-DF with TEB}

The green roof design retained for GREENROOF allows for four distinct compartments or layers to be modelled (Fig. 1): from top to bottom, a compartment for vegetation which interacts with the atmosphere, a layer of substrate (in which lies the root system of the vegetation), a layer that controls the hydrological exchange with the substrate above (retention/drainage layer) and a compartment to represent the structural building and any artificial roof layers installed 
(waterproofing or thermal insulation membranes and layers of the bearing roof).

Modelling this physical design within GREENROOF implies a configuration with two models: ISBA-DF to simulate the exchange of heat and water in the natural layers of the roof, and TEB to simulate heat exchange within the artificial layers of the roof which have no biological role and within which no transfer of water is involved. The structure of the resulting source code is presented in Fig. 2. This two-scheme configuration requires implementation of a thermal coupling between the base of the hydrological control layer (managed by ISBA-DF) and the artificial layers of the roof (managed by TEB). This coupling is realized in two ways - one way through the interfacial heat conduction flux, the other way via the temperatures of the layers in contact. TEB is coupled to ISBA through the interfacial heat conduction flux $\left(G_{N-R}\right)$ that establishes between the deepest sub-layer (referred to as layer $n$ ) of the natural green roof and the top sub-layer (layer 1) of the artificial roof with which the natural roof is in contact:

$G_{N-R}=\bar{\lambda}_{N-R}\left(T_{N_{n}}-T_{R_{1}}\right)$,

$T_{N_{n}}$ and $T_{R_{1}}$ are, respectively, the temperatures of the deepest sub-layer of the natural roof and the top layer of the artificial roof. $\bar{\lambda}_{N-R}$ is the interfacial thermal conductivity between the two layers, approximated by

$\bar{\lambda}_{N-R}=\frac{2 \lambda_{N_{n}}}{\Delta z_{N_{n}}}$,

with $\lambda_{N_{n}}$ the effective thermal conductivity of the bottom layer of the natural roof and $\Delta z_{N_{n}}$ its thickness. This modifies the equation predicting the temperature evolution of the top layer of the structural roof (Eq. 1a of Masson, 2000):

$$
\begin{aligned}
C_{R_{1}} & \frac{\partial T_{R_{1}}}{\partial t}=\frac{\left(1-f_{G R}\right)}{d_{R_{1}}}\left(Q_{R_{1}}^{*}-H_{R_{1}}-\mathrm{LE}_{R_{1}}-G_{R_{1}-R_{2}}\right) \\
& +\frac{f_{G R}}{d_{R_{1}}}\left(G_{N-R}-G_{R_{1}-R_{2}}\right),
\end{aligned}
$$

where $C_{R_{1}}$ is the thermal capacity of the artificial layer in contact with the natural roof; $f_{G R}$ the fraction of roof vegetated; and $Q_{R_{1}}^{*}, H_{R_{1}}, \mathrm{LE}_{R_{1}}, G_{R_{1}-R_{2}}$ the terms of the surface energy balance for the fraction of roof not vegetated.

Then, to ensure the continuity in temperature, ISBA is coupled to TEB by recalling the temperature of the deepest layer of the green roof to that of the top artificial layer of the structural building at each time step.

Due to the presence of waterproofing membranes, no hydrological coupling is required between the soil-vegetation model and the building model, and the excess water and the water that percolates leaves the system and are collated as the "green roof outlet drainage". This will allow for connection to urban drainage systems when these are developed within a future version of TEB.

\subsection{GREENROOF input parameters}

For a given green roof design, the three natural compartments implemented in the GREENROOF module (vegetation, substrate and hydrological control layers) can be initialized (Table 1). The study of the scientific and technical literature shows that the plant species the most commonly used on green roofs are grasses (Gramineae) or sedums (Sedum) or a mixture of both. However, sedums are more frequently used for green roofs implemented under a dry climate due to their ability to stand the conditions inherent in this type of climate. Sedums are low-growing succulent plants of the Crassulaceae family, and are categorized as crassulacean acid metabolism (CAM) plants, CAM being one of three mechanisms for the uptake of $\mathrm{CO}_{2}$ (photosynthesis) with $\mathrm{C} 3$ and C4. Under the CAM photosynthesis pathway, sedums can withstand long periods of heat and water stress (Carter and Butler, 2008; Durhman et al., 2006; Van Woert et al., 2005; Wolf and Lundholm, 2008) by partially closing their stomata during the day (hence reducing or inhibiting transpiration), and opening them at night to fix $\mathrm{CO}_{2}$ for later use in photosynthesis. Many sedums are facultative CAM, meaning that they can switch to a $\mathrm{C} 3$ photosynthetic pathway when water is again available. This ability makes them very water-useefficient, which is why they are well adapted for extensive green roofs (thin layer of growing medium). However this photosynthetic pathway CAM (or CAM-C3) is not parameterized in standard vegetation models (including ISBA), and even providing standard input values for this type of vegetation is a delicate task because few data have been published. Even if the lack of data did not allow for a parameterization of sedum transpiration mechanisms to be established and implemented in GREENROOF, an attempt to characterize sedums for ISBA-DF has been undertaken, bearing in mind the objective to eventually simulate the differences in characteristics and functioning inherent to the two types of vegetation commonly found on green roofs. To this end, two options for green roof vegetation have been established in GREENROOF and are provided to the user: the GRASS option (herbaceous lawn) and the SEDUM option (sedum lawn). Default characteristics for GRASS were already available in the standard version of ISBA-DF. A set of values was finally collected in the literature to characterize the type $S E$ DUM (Table 2).

Ultimately, it is mainly the characterization of the substrate and hydrological layers which is a crucial and challenging step as the soil-forming materials implemented on green roofs are very different from the standard soils. This is discussed further in the next paragraph via a case study. The characterization of the artificial layers (Table 1) which may be added to the initial roof upon green roof implantation (such as insulation or waterproofing layers) is performed within the TEB model. 
Table 1. GREENROOF model input parameters ( $\mathrm{T}$ and $\mathrm{H}$ refer respectively to a thermal and a hydrological parameter).

\begin{tabular}{|c|c|}
\hline & Parameter (unit) \\
\hline Design & $\begin{array}{l}\text { Fraction of structural roof vegetated (-) } \\
\text { Number of green roof sub-layers used for calculation and their respective depths (m) }\end{array}$ \\
\hline Vegetation & $\begin{array}{l}\text { Type (herbaceous lawn or sedum lawn) } \\
\text { Fraction of vegetation covering the vegetated ground (-) } \\
\text { LAI (-) } \\
\text { Albedo (-) } \\
\text { Emissivity (-) } \\
\text { Minimum stomatal resistance }\left(\mathrm{s} \mathrm{m}^{-1}\right) \\
\text { Roughness length for momentum (m) }\end{array}$ \\
\hline $\begin{array}{l}\text { Substrate and hydrological } \\
\text { control sub-layers }\end{array}$ & $\begin{array}{l}\text { Initial soil moisture (soil water index) for surface, root layers and hydrological sub- } \\
\text { layers } \\
\text { Initial soil-forming-material temperature for surface, root layers and hydrological sub- } \\
\text { layers }\end{array}$ \\
\hline $\begin{array}{l}\text { Substrate and hydrological con- } \\
\text { trol sub-layers }\end{array}$ & $\begin{array}{l}\text { T: Dry soil thermal conductivity }\left(\mathrm{W} \mathrm{m}^{-1} \mathrm{~K}^{-1}\right) \\
\text { T: Dry soil heat capacity }\left(\mathrm{J} \mathrm{m}^{-3} \mathrm{~K}^{-1}\right) \\
\text { H: Porosity }\left(\mathrm{m}^{3} \mathrm{~m}^{-3}\right) \\
\text { H: Saturated hydraulic conductivity }\left(\mathrm{m} \mathrm{s}^{-1}\right) \\
\mathrm{H} \text { : Matrix potential at saturation }(\mathrm{m}) \\
\mathrm{H} \text { : } b \text { coefficient for water retention curve }(-) \\
\mathrm{H} \text { : Water content at field capacity }\left(\mathrm{m}^{3} \mathrm{~m}^{-3}\right)^{\mathrm{a}} \\
\mathrm{H} \text { : Water content at wilting point }\left(\mathrm{m}^{3} \mathrm{~m}^{-3}\right)^{\mathrm{a}}\end{array}$ \\
\hline $\begin{array}{l}\text { Artificial layers added to the } \\
\text { structural roof (TEB) }\end{array}$ & $\begin{array}{l}\text { Total number of layers of the artificial roof and their respective thicknesses (m) } \\
\text { Albedo of the top artificial layer }(-) \\
\text { Emissivity of the top artificial layer }(-) \\
\text { Thermal conductivity }\left(\mathrm{W} \mathrm{m}^{-1} \mathrm{~K}^{-1}\right) \\
\text { Heat capacity }\left(\mathrm{J} \mathrm{m}^{-3} \mathrm{~K}^{-1}\right)\end{array}$ \\
\hline
\end{tabular}

a for hydrological control sub-layers, only used to initialize water contents.

Table 2. Vegetation characteristics for SEDUM compared to those of GRASS (defined according to the default values proposed by Masson et al., 2003).

\begin{tabular}{llll}
\hline GREENROOF parameter (unit) & Value (GRASS) & Value (SEDUM) & Method for SEDUM (Source) \\
\hline Fraction of vegetation covering the ground $(-)$ & 0.9 & 0.9 & Chosen identical to that of GRASS \\
Leaf area index (-) & 2 & 3 & Measured (CRITT Horticole, 2012) \\
Longwave albedo (-) & 0.300 & 0.154 & Measured (Doya, 2011) \\
Shortwave albedo (-) & 0.100 & 0.154 & Measured (Doya, 2011) \\
Emissivity (-) & 0.95 & 0.83 & Measured (Feng et al., 2010) \\
Minimal stomatal resistance ( $\mathrm{s} \mathrm{m}^{-1}$ ) & 40 & 150 & Chosen higher than that for GRASS (Sect. 3.3) \\
Roughness length for momentum (m) & 0.01 & 0.01 & Chosen identical to that of GRASS \\
\hline
\end{tabular}

\section{Calibration and evaluation of GREENROOF for a standard case study}

For standard applications of ISBA to natural soils, the thermal characteristics for dry soil and the hydrological characteristics are deduced from empirical formulations, called pedotransfer functions, which connect these characteristics to the user-input soil texture properties (sand and clay fractions, Decharme et al., 2011). But the pedotransfer functions derived for natural soils are not really adapted to the soil-forming materials constituting the substrate or the drainage layers of a green roof. Consequently, whenever possible, it is better to directly input GREENROOF with greenroof-specific thermal and hydrological characteristics. However, when thermal characteristics for green roof materials are available, hydrological characteristics are not only hard to find but also consist in lab measurements which do not reflect in situ conditions such as soil compaction or root presence/growth. Indeed, root growth results in the formation of 


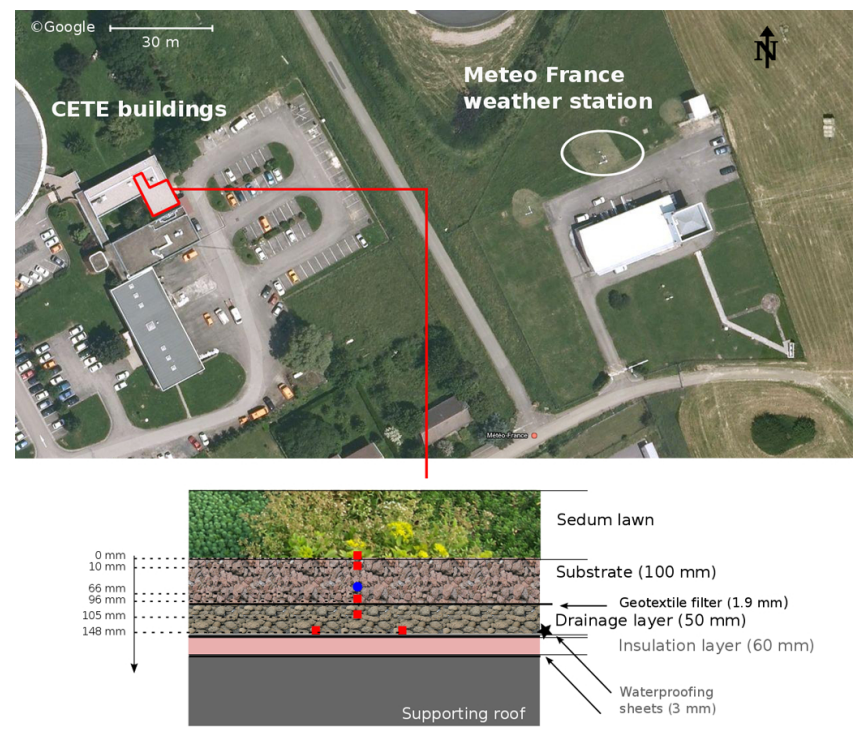

Fig. 3. Location (top) and design (bottom) of the green roof experimental plot modelled, showing the positions of the various sensors (red squares for temperature sensors, blue circle for water content and matrix potential sensor and star for drainage water gauge).

soil microstructures, which modifies the intrinsic soil hydrological behaviour. Consequently, a calibration exercise is undertaken to best fit green roof hydrological characteristics to in situ conditions as well as to the GREENROOF module.

\subsection{Case study experimental data}

The GREENROOF module is evaluated against observations at a single site. This exercise is based on the experiment conducted by the Centre d'Etudes Techniques de l'Equipement de l'Est [CETE] in the northeast of France near the city of Nancy. The research team at the CETE has designed an experiment with the aim of studying the relations between the thermal and hydrological characteristics of green roof systems and their thermal and hydrological behaviours for a set of vegetation/substrate/drainage layer combinations (Fig. 3). Due to their location, the plots are exposed to a temperate oceanic climate.

The green roof plot studied, whose surface is $75 \mathrm{~m}^{2}$, is composed of three natural layers of significant thicknesses (Fig. 3): a vegetation layer, a manufactured growing medium (substrate) and a drainage layer underneath. In addition, the transfer of fine substrate particles into the drainage layer is prevented by a $1.9 \mathrm{~mm}$ thick filter sheet which lets the water pass (geotextile material with high hydrological conductivity). In order to improve the energy performance of the building, an insulating layer of $60 \mathrm{~mm}$ has been installed between the base of the green roof compartment and the structural roof. Finally, two $3 \mathrm{~mm}$ thick waterproofing membranes on either side of the insulating layer prevent water damage to the insulator and the structural roof. The vegetation is a freshly established (2-month old) sedum lawn consisting of a mixture of seven species (Sedum album, Sedum reflexum larix, Sedum reflexum germanium, Sedum spurium, Sedum sexangulare, Sedum floriferum, and Sedum hispanicum: Fig. 3). The substrate, manufactured by the firm Falienor, is widely used in extensive green roof implementations. The drainage layer consists of expanded clay granules $(2-10 \mathrm{~mm}$ grain size) manufactured by the firm Leca ${ }^{\circledR}$. Therefore, this green roof plot is fairly representative of the green roofs which are nowadays implemented in cities.

The evolution of the thermal and hydrological status within the green roof is recorded as shown in Fig. 3. Soil temperatures are recorded using PT100 sensors at different depths, including the soil surface, near the centre of the plot $(0,10,96,105$ and $148 \mathrm{~mm})$. Soil water content and matrix potential are provided by a TDR probe at a single depth $(66 \mathrm{~mm})$, and the excess water which is drained out of the substrate and drainage layers is measured with a tippingbucket water gauge at the base of the green roof (water outlet). In addition, a weather station situated on the roof at $1.40 \mathrm{~m}$ above green roof surface provides air temperature, wind speed and relative humidity as well as global incoming solar radiation at a $10 \mathrm{~min}$ temporal resolution. The time series available for all of these data run from 4 July to 29 November 2011.

\subsection{Numerical setup for the case study}

This study focuses on the green-roofed plot and its surrounding environment, the scale at which observations are available. Consequently, simulations are carried out on one grid point. To simulate atmospheric conditions to which the green roof is exposed, a series of locally observed meteorological fields are prescribed hourly to the GREENROOF module: atmospheric pressure, shortwave incoming solar radiation (direct and diffuse), longwave incoming radiation, air temperature and relative humidity, average wind speed and precipitation (rain and snow). The weather station installed on the greened roof provides air temperature and relative humidity, as well as average wind speed and global incoming solar radiation. The global incoming solar radiation is assumed to be about $80 \%$ direct and $20 \%$ diffuse. Precipitation and atmospheric pressure are provided by the nearest Météo France weather station (which is about $130 \mathrm{~m}$ from the green roof plot; see Fig. 3). Finally, since the infrared incoming radiation ( $\mathrm{LW}^{\downarrow}$ ) which must be prescribed to the model is not available at any of the two stations, it is firstly established for clear sky conditions ( $\mathrm{LW}_{\mathrm{CS}}^{\downarrow}$ ) according to the StefanBoltzmann law (Eq. 9), with air emissivity $\left(\varepsilon_{\mathrm{a}}\right)$ calculated according to Prata (1996) after its temperature $\left(T_{\mathrm{a}}\right)$ and humidity. Then it is modulated following Diak et al. (2000) to account for the longwave re-emission of the cloud cover ( $f_{\mathrm{C}}$ observed at the nearest Météo France weather station, Eq. (10) - assuming that the cloud temperature is equivalent to that of the surrounding air and cloud emissivity is equal 
to 1$)$.

$\mathrm{LW}_{\mathrm{CS}}^{\downarrow}=\varepsilon_{\mathrm{a}} \sigma T_{\mathrm{a}}^{4}$

$$
\mathrm{LW}^{\downarrow}=\left(1-f_{\mathrm{C}}\right) \mathrm{LW}_{\mathrm{CS}}^{\downarrow}+f_{\mathrm{C}} \sigma T_{\mathrm{a}}^{4},
$$

where $\sigma$ is the Stefan-Boltzmann constant.

To model the studied plot with GREENROOF, the three natural layers of the roof (vegetation, substrate and drainage layer) are simulated by the ISBA-DF model, while the artificial layers (the two waterproofing membranes on either sides of the insulator, and the initial structural layers of the roof) are simulated by the TEB model. Both the thermal and hydrological influences of the particle filter are considered negligible because of its low thickness and high water conductivity. Finally, to ensure numerical stability in model runs, and in order to extract temperature and water content model estimates at the same vertical levels as those measured on the plot, the substrate and drainage layers were subdivided respectively into three and two vertical sub-layers.

\subsection{Initialization of green roof thermal parameters}

Values for radiative and thermal characteristics (referred to as $\mathrm{T}$ in Table 1) of all green roof layers, be they natural or artificial, were either recovered from the technical literature (suppliers or manufacturers of similar products), measured by Bouzouidja (in the laboratory or in situ on the study plot) or retrieved from the scientific literature. A compilation of these values is presented in Table 3. Note that the value retained for the dry soil thermal conductivity of the case study substrate is within the range of thermal conductivities reported in Sailor (2008) for eight different green roof substrates at $0 \%$ soil moisture $\left(0.14-0.21 \mathrm{~W} \mathrm{~m}^{-1} \mathrm{~K}^{-1}\right)$, and this information is well correlated with the substrate density $\left(800-851 \mathrm{~kg} \mathrm{~m}^{-3}\right.$ according to Bouzouidja, 2012, and Falienor, 2010). Its heat capacity is slightly above the range of those measured by Sailor et al. (2008: 950760-1246000 $\mathrm{J} \mathrm{m}^{-3} \mathrm{~K}^{-1}$ ) but of a similar order of magnitude.

\subsection{Methodology for the calibration of green roof hydrological parameters}

The first step of this calibration consists in compiling the values available, for each of the six hydrological characteristics needed as model inputs, (referred to as $\mathrm{H}$ in Table 1) in the same way as for thermal parameters (technical and scientific literature, measurements). The water contents at field capacity and wilting point are prescribed from in situ observations, leaving only four hydrological characteristics to initialize for both the substrate and the drainage layer: the porosity, which represents the maximum interstitial space available for water; the saturated hydraulic conductivity, which corresponds to the infiltration rate of the water when the soil is saturated; the soil matrix potential at saturation, which corresponds to the pressure required to extract water from a soil matrix saturated with water; and finally the coefficient of the water retention curve used in ISBA, called $b$, which relates the matrix potential to the water content of a soil matrix according to the formulation of Clapp and Hornberger (1978). The $b$ coefficient is an empirical coefficient which varies according to soil type, and can be determined by regression based on observations. This method can be used for the substrate layer for which the hydrological status is continuously recorded (Fig. 3), and is applied to two sets of relevant porositymatrix-potential combination (developed in Appendix A).

Things are slightly more complex for the drainage layer. Indeed, due to the double porosity of this layer (macroporosity of the matrix and microporosity of the expanded clay granules) and the lack of data for initializing the matrix potential at saturation and $b$ coefficient, a calibration exercise is run. The objective of this exercise is to determine - from three typical hydrological behaviours, organic matter (OM), SAND or CLAY - the one that best corresponds to this soilforming material in GREENROOF. Therefore, the calibration exercise consists in running three simulation ensembles differing in the initialization of their drainage layer. Based on the green roof hydrological characteristics listed in Table 4, ensemble members are obtained by the combination of two drainage layer parameter values (matrix potential at saturation and $b$ coefficient, written in italics in Table 4) with all the other substrate-drainage characteristic values, resulting in 32 simulations per ensemble. Each of them is then run and the outputs are compared against local observations to identify the best ensemble to model the hydrology of the case study plot.

The calibration period is chosen carefully, firstly to calibrate GREENROOF at a time when many processes are active (presence of rain, vegetation fully developed and photosynthetically active), and secondly when the plot conditions are closest to what GREENROOF is capable of modelling. Indeed, a device with stoppers has been installed between the green roof base and the tipping-bucket water gauge. This device may allow for a water blade of varying height to be retained, when it exists, by using these stoppers placed at different heights of the outlet (multiples of $15 \mathrm{~mm}$ ). It is intended to keep water on the roof for use during dry spells or to delay and reduce roof runoff peaks during heavy rainfall events. Obviously, this device, which consists in an experimental setup, could complicate the analysis of the calibration exercise presented herein since it prevents part of the water that is drained out of the drainage layer from being recorded. As GREENROOF does not seek to simulate this device, which is not generally implemented on green roofs, and as the dates at which these stoppers were installed are known (two stoppers between 10 July and 8 August and between 28 October and 29 November, one stopper between 9 August and 27 October 2011), the calibration period chosen was when fewer stoppers were installed, from 10 August to 9 September 2011. 
Table 3. General and thermal characteristics of green roof substrate, drainage layers and roof artificial layers (values in bold are used in simulations).

\begin{tabular}{|c|c|c|c|}
\hline & Characteristics (unit) & Value & Method (Source) \\
\hline \multirow{3}{*}{ SUBSTRATE } & Thickness (m) & 0.08 & Measured (Bouzouidja, 2012) \\
\hline & $\begin{array}{l}\text { Dry unit weight of soil particles } \\
\left(\mathrm{kg} \mathrm{m}^{-3}\right)\end{array}$ & 2610 & Deduced from Falienor (2010) \\
\hline & $\begin{array}{l}\text { Dry soil thermal conductivity } \\
\left(\mathrm{W} \mathrm{m}^{-1} \mathrm{~K}^{-1}\right)\end{array}$ & 0.15 & Measured $^{\mathrm{a}}$ (Bouzouidja, 2010) \\
\hline \multirow{3}{*}{ DRAINAGE } & Thickness (m) & 0.05 & Measured (Bouzouidja, 2012) \\
\hline & $\begin{array}{l}\text { Dry unit weight of soil particles } \\
\left(\mathrm{kg} \mathrm{m}^{-3}\right)\end{array}$ & 570 & Supplier information $\left(\right.$ Leca $\left.^{\circledR}, 2009\right)$ \\
\hline & $\begin{array}{l}\text { Dry soil heat capacity } \\
\left(\mathrm{J} \mathrm{m}^{-3} \mathrm{~K}^{-1}\right)\end{array}$ & 331500 & $\begin{array}{l}\text { Deducted from manufacturer information (Sinclair, } \\
\text { 2012) according to density }\end{array}$ \\
\hline \multirow{3}{*}{ ARTIFICIAL } & $\begin{array}{l}\text { Material/function } \\
5 \text { layers, from top (1) to bot- } \\
\text { tom (5) }\end{array}$ & $\begin{array}{l}\text { (1) waterproofing membrane } \\
\text { (2) insulating sheet }\left(\mathrm{PIR}^{\mathrm{c}}\right) \\
\text { (3) waterproofing membrane } \\
\text { (4) insulator } \\
\text { (5) concrete }\end{array}$ & $\begin{array}{l}\left.\text { (1) Supplier information (SOPREMA }{ }^{\circledR}, 2012 a\right) \\
\text { (2) ACERMI (2009) } \\
\text { (3) Supplier information (SOPREMA }{ }^{\circledR}, 2012 b \text { ) } \\
\text { (4 to 5) Deducted from building type and age } \\
\text { (Lemonsu et al., 2011) }\end{array}$ \\
\hline & Thickness (m) & $\begin{array}{l}\text { (1) } 0.003 \\
\text { (2) } 0.060 \\
\text { (3) } 0.003 \\
\text { (3) } 0.10 \\
\text { (4) } \mathbf{0 . 2 0}\end{array}$ & $\begin{array}{l}\text { (1) Supplier information (SOPREMA }{ }^{\circledR}, 2012 \mathrm{a} \text { ) } \\
\text { (2) Supplier information (RECTICEL }{ }^{\circledR}, 2012 \text { ) } \\
\text { (3) Supplier information (SOPREMA }{ }^{\circledR}, 2012 \mathrm{~b} \text { ) } \\
\text { (4 and 5) Deducted from building type and age } \\
\text { (Lemonsu et al., 2011) }\end{array}$ \\
\hline & Heat capacity $\left(\mathrm{J} \mathrm{m}^{-3} \mathrm{~K}^{-1}\right)$ & $\begin{array}{l}\text { (1) } 2100000 \\
\text { (2) } 44800 \\
\text { (3) } 2100000 \\
\text { (4) } 75000 \\
\text { (4) } 2300000\end{array}$ & $\begin{array}{l}\text { ( } 1 \text { and 3) Deducted from building type, age and } \\
\text { usage (Lemonsu et al., 2011) } \\
\text { (2) Deducted from BING (2006) and Kalzip }{ }^{\circledR} \\
\text { (2010) based on density (RECTICEL }{ }^{\circledR}, 2012 \text { ) } \\
\text { (4 and 5) Deducted from building type, age and } \\
\text { usage (Lemonsu et al., 2011) }\end{array}$ \\
\hline
\end{tabular}

${ }^{a}$ for a similar substrate, mean between -10 and $50{ }^{\circ} \mathrm{C} .{ }^{b}$ for a similar substrate, at $20^{\circ} \mathrm{C} .{ }^{\mathrm{c}}$ polyisocyanurate foam with aluminium layer.

Over the calibration period, a systematic calculation of simulation statistical scores is undertaken to compare GREENROOF results to observations by focusing on the hydrological variables available on site (substrate water content and outlet drainage). The Pearson coefficient of correlation $(R)$, the root-mean-square error (RMSE), the mean bias error
(MBE) and the standard deviation (SD) are computed. For the sake of visualization, $R$ as well as the centred RMSE and the standard deviations (SD) of both the models and observations are initially plotted on a Taylor diagram (Taylor, 2001). 
Table 4. Hydrological characteristics tested for green roof calibration exercise.

\begin{tabular}{|c|c|c|c|}
\hline & Characteristics (unit) & Value & Method (Source) \\
\hline \multirow{6}{*}{ SUBSTRATE } & Porosity $\left(\mathrm{m}^{3} \mathrm{~m}^{-3}\right)$ & $\begin{array}{l}0.674 \\
0.411\end{array}$ & $\begin{array}{l}\text { Supplier information (Falienor, 2010) } \\
\text { Measured (Bouzouidja, 2012) }\end{array}$ \\
\hline & Saturated hydraulic conductivity $\left(\mathrm{m} \mathrm{s}^{-1}\right)$ & $\begin{array}{l}1.073 \times 10^{-3} \\
2.162 \times 10^{-3}\end{array}$ & $\begin{array}{l}\text { Supplier information (Falienor, 2010) } \\
\text { Measured (Bouzouidja, 2012) }\end{array}$ \\
\hline & Matrix potential at saturation $(\mathrm{m})$ & -0.10 & $\begin{array}{l}\text { Value fitted on observed water retention curves } \\
\text { (Appendix A) }\end{array}$ \\
\hline & $b$ coefficient for water retention curve $(-)$ & $\begin{array}{l}2.9 \\
3.9\end{array}$ & $\begin{array}{l}\text { Deducted from water retention curve (Fig. A1) } \\
\text { porosity of } 0.674 \text { and matrix potential of }-0.10 \\
\text { Deducted from water retention curve (Fig. A2) } \\
\text { with porosity of } 0.411 \text { and matrix potential of } \\
-0.10\end{array}$ \\
\hline & Water content at field capacity & 0.37 & Deducted from observations \\
\hline & Water content at wilting point $\left(\mathrm{m}^{3} \mathrm{~m}^{-3}\right)$ & 0.15 & Deducted from observations \\
\hline \multirow{5}{*}{ DRAINAGE } & Porosity $\left(\mathrm{m}^{3} \mathrm{~m}^{-3}\right)$ & $\begin{array}{l}0.553 \\
0.9\end{array}$ & $\begin{array}{l}\text { Deducted from supplier density data (Table } 3 \text { ) } \\
\text { Literature (Ochs et al., 2006) \& manufacturer } \\
\text { information (Argex, 2012) }\end{array}$ \\
\hline & Saturated hydraulic conductivity $\left(\mathrm{m} \mathrm{s}^{-1}\right)$ & $\begin{array}{l}3.32 \times 10^{-3} \\
1 \times 10^{-2}\end{array}$ & $\begin{array}{l}\text { (Bouzouidjam, 2012) } \\
\text { Technical specification }\left(\text { Leca }^{\circledR}, 2012\right)\end{array}$ \\
\hline & $\begin{array}{l}\text { Matrix potential at saturation }(m) \\
b \text { coefficient for water retention curve }(-)\end{array}$ & $\begin{array}{l}-0.010 \\
2.7\end{array}$ & $\begin{array}{l}\text { Values for organic matter } \\
\text { (Lawrence and Slater, 2008) }\end{array}$ \\
\hline & $\begin{array}{l}\text { Matrix potential at saturation }(m) \\
b \text { coefficient for water retention curve }(-)\end{array}$ & $\begin{array}{l}-0.121 \\
4.05\end{array}$ & $\begin{array}{l}\text { Values for sand in ISBA } \\
\text { (Clapp and Hornberger, 1978) }\end{array}$ \\
\hline & $\begin{array}{l}\text { Matrix potential at saturation }(m) \\
b \text { coefficient for water retention curve (-) }\end{array}$ & $\begin{array}{l}-0.405 \\
11.4\end{array}$ & $\begin{array}{l}\text { Values for clay in ISBA } \\
\text { (Clapp and Hornberger, 1978) }\end{array}$ \\
\hline
\end{tabular}

\subsection{Determination of the best hydrological ensemble for the case study}

The Taylor diagrams for daily outlet drainage and substrate water content are presented in Fig. 4. They demonstrate different behaviours for the three ensembles. The model performance in estimating substrate water content (Fig. 4, left) is better for the OM ensemble than for the SAND and the CLAY ensembles, and is acceptable, with a correlation ranging from 0.6 to nearly 0.85 . Two subsets can be identified within the OM ensemble; subset 1 has a slightly lower $R$, a better SD and a slightly better centred RMSE than subset 2 . The scores for the substrate water content are in coherence with the scores for the daily outlet drainage (Fig. 4, right): they are also better for the OM ensemble than for the other two, in the same order of performance (performance $\mathrm{OM}>$ performance SAND > performance CLAY). The correlation coefficient ranges from 0.6 to 0.8 , and this time, the two OM subsets present different SD and centred RMSE, the water content subset 2 being the outlet drainage subset, with the SD the closest to observations $\left(0.12 \mathrm{~m}^{3}\right.$ day $\left.^{-1}\right)$ and the smallest centred RMSE (around $0.1 \mathrm{~m}^{3}$ day $^{-1}$ ).

Figures 5 and 6 present the evolution of the two variables of interest over the calibration period for each of the three ensembles and their means, as well as additional statistical scores. They confirm that the OM ensemble systematically better suits the observations than SAND and CLAY ensembles, be it for the substrate water content or the outlet drainage. In Fig. 5, for the substrate water content, the mean bias error (MBE) of the OM ensemble mean is $-0.10 \mathrm{~m}^{3} \mathrm{~m}^{-3}$, and those of the SAND and CLAY ensemble means respectively two and three times more. Figure 6 demonstrates similar results for the outlet drainage, with a percentage bias error (PBE) of $+121,+310$ and $+337 \%$ for the OM, SAND and CLAY ensemble means respectively, resulting in an excess of $1.4,3.5$ and $3.8 \mathrm{~m}^{3}$ being drained out of the green roof over the calibration period. These better biases for the OM ensemble are also associated with better RMSEs, be it for the substrate water content $\left(0.11 \mathrm{~m}^{3} \mathrm{~m}^{-3}\right.$ against 0.24 and 0.30 for the SAND and 

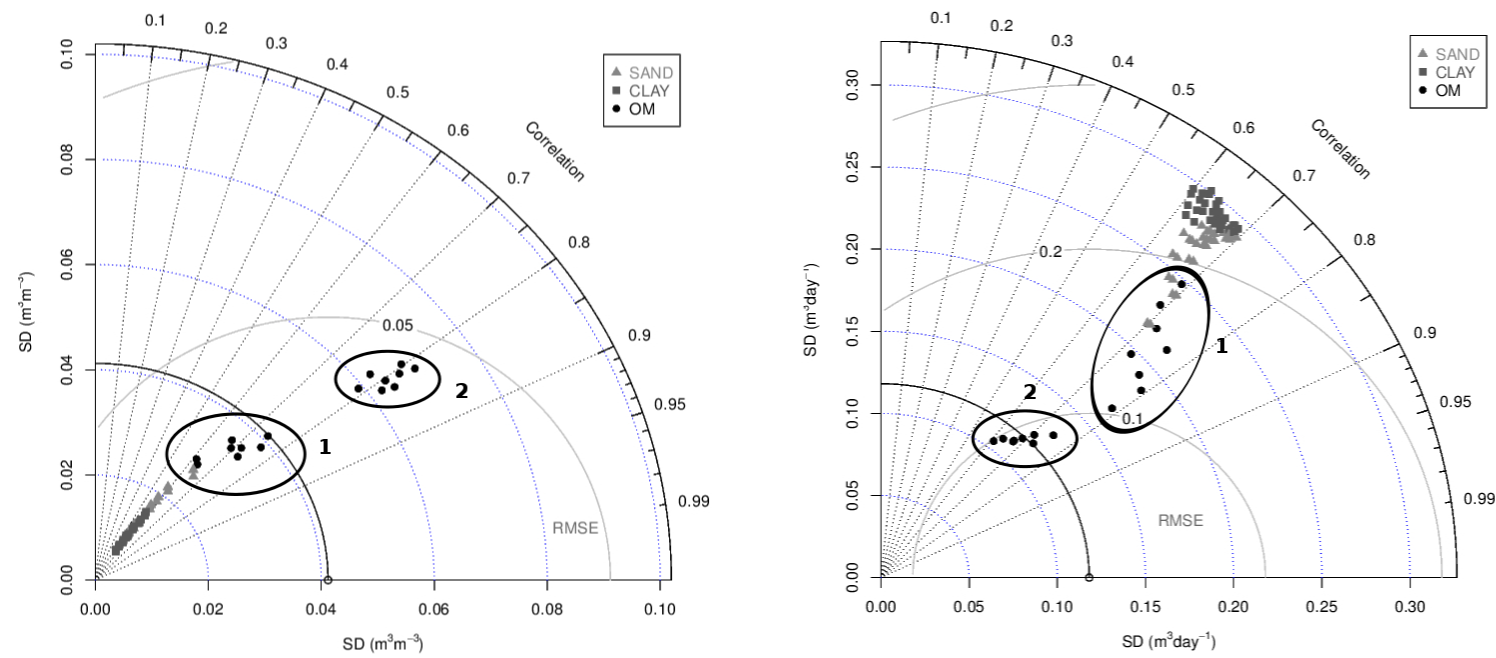

Fig. 4. Taylor diagrams showing the performance of three model ensembles differing in the hydrological calibration of the DRAINAGE layer (OM, SAND and CLAY) to model (left) the water content recorded at $77 \mathrm{~mm}$ depth in the green roof substrate and (right) the green roof daily outlet drainage. On each diagram, a dot is assigned to each of the 96 models. One can read $R$ on the right-hand side of each quadrant, SD radially ( $\mathrm{SD}_{\mathrm{OBS}}$ is shown by a black quadrant, at $0.041 \mathrm{~m}^{3} \mathrm{~m}^{-3}$ for water content and $0.12 \mathrm{~m}^{3}$ day ${ }^{-1}$ for drainage), and the centred RMSE on grey semicircles centred on the observations' SD. The ideal model that would fit the observations is represented by the black circle $\left(R=1 ; \mathrm{RMSE}=0 ; \mathrm{SD}=\mathrm{SD}_{\mathrm{OBS}}\right)$.
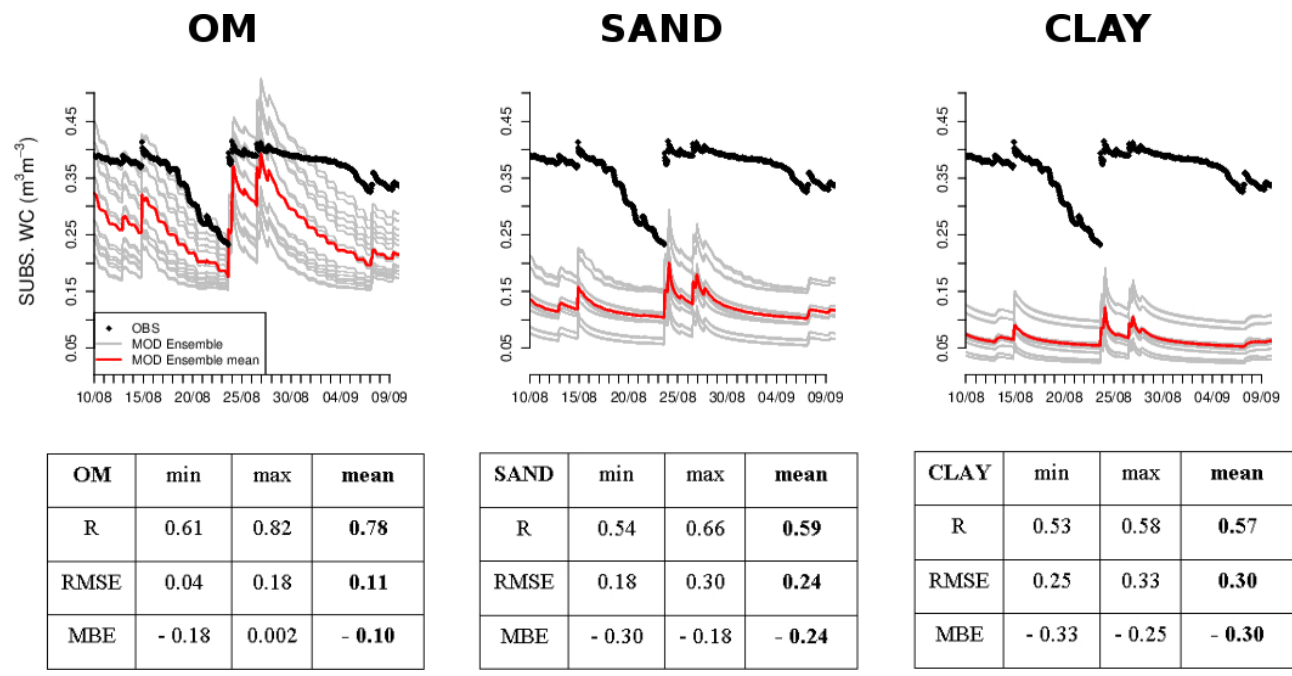

Fig. 5. Comparison of the three ensemble simulations OM, SAND and CLAY with regard to their ability to model substrate water content over the calibration period (10 August 2011-9 September 2011). Graphs represent the evolution of the water content with time for each ensemble, while the tables gather their respective scores. $R$ is the correlation coefficient $(-)$, RMSE the root-mean-square error and MBE the mean bias error $\left(\mathrm{m}^{3} \mathrm{~m}^{-3}\right)$.

CLAY ensembles) or the outlet drainage $\left(0.10 \mathrm{~m}^{3}\right.$ day $^{-1}$ versus 0.23 and 0.26 for the SAND and CLAY ensembles). Even with the best ensemble simulations, GREENROOF tends to underestimate the water content in the substrate, while overestimating the drainage collected at the green roof base. The stopper in place at the base of the green roof might explain part of this positive bias since some of the water drained from the substrate and the drainage layer is retained at the green roof base instead of being evacuated towards the roof outlet. In addition, the model always simulates a "background" drainage" even when none is observed, which contributes to this positive bias.

Finally, the best calibration ensemble obtained for the drainage layer - whose texture, porosity and hydrological behaviour are complex - displays hydrological characteristics which are all typical of the behaviour of organic matter (peat): high porosity and saturated hydraulic conductivity matched to a low $b$ coefficient (according to Lawrence and 

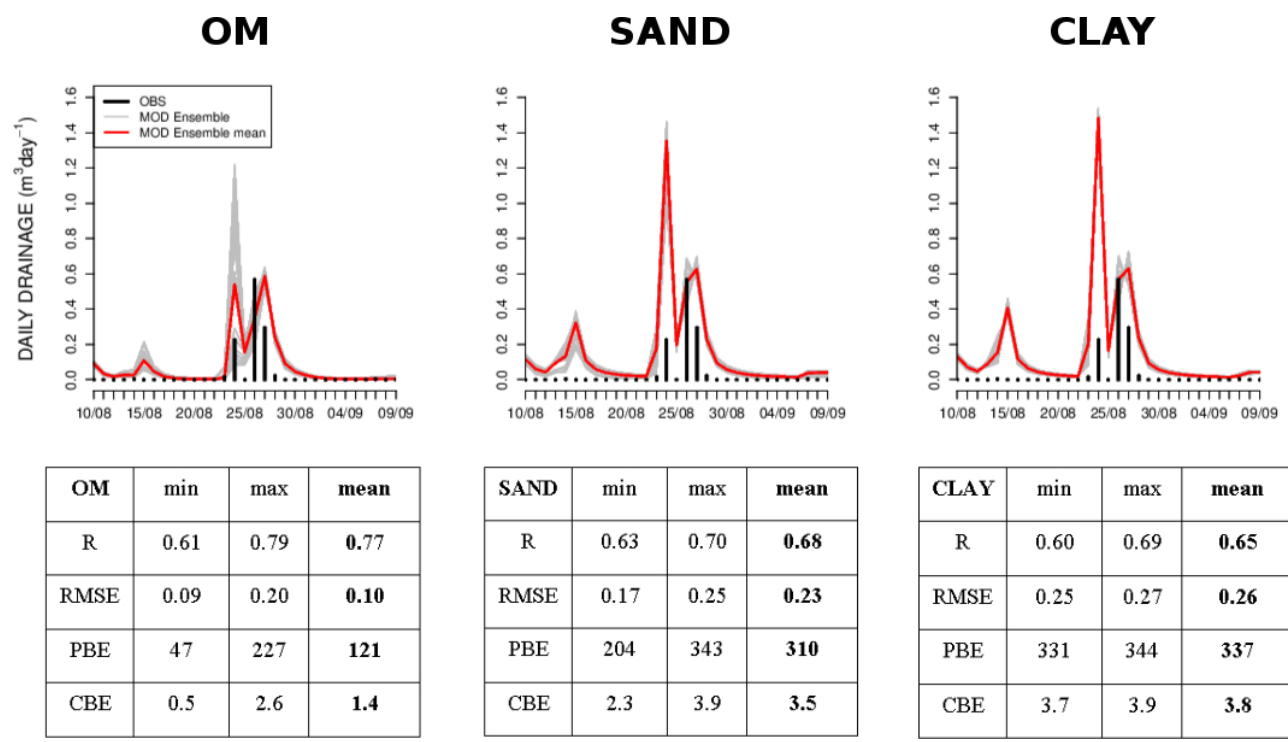

\begin{tabular}{|c|c|c|c|}
\hline CLAY & $\min$ & $\max$ & mean \\
\hline $\mathrm{R}$ & 0.60 & 0.69 & $\mathbf{0 . 6 5}$ \\
\hline RMSE & 0.25 & 0.27 & $\mathbf{0 . 2 6}$ \\
\hline $\mathrm{PBE}$ & 331 & 344 & $\mathbf{3 3 7}$ \\
\hline $\mathrm{CBE}$ & 3.7 & 3.9 & $\mathbf{3 . 8}$ \\
\hline
\end{tabular}

Fig. 6. Comparison of the three ensemble simulations OM, SAND and CLAY with regard to their ability to model daily outlet drainage over the calibration period (10 August 2011-9 September 2011). Graphs represent the evolution of the outlet drainage with time for each ensemble, while the tables gather their respective scores. $R$ the correlation coefficient $(-)$, RMSE the root-mean-square error $\left(\mathrm{m}^{3} \mathrm{day}^{-1}\right)$, PBE the mean bias error (\%) and CBE the bias error cumulated over the entire calibration period $\left(\mathrm{m}^{3}\right)$. For reference, the total outlet drainage observed over this period of time equals $1.1 \mathrm{~m}^{3}$.

Slater, 2008). This information is an interesting outcome because it allows for one to relate the hydrological behaviour of expanded clay granules to a better known soil component. This best calibration ensemble will next be used to evaluate the GREENROOF model hydrological and thermal performances over the remaining time series.

\subsection{Evaluation of GREENROOF hydrological and thermal performances}

\subsubsection{Hydrological performance}

The evolution of the substrate water content and the green roof drainage over the entirety of the time series available are presented in Fig. 7 for the OM ensemble calibrations and the two OM subsets to illustrate their discrepancies in relation to that of their statistical scores (Table 5) calculated over the evaluation period running from 10 September to 29 November 2011.

Starting with the substrate water content, GREENROOF scores over the evaluation period are similar (RMSE and $\mathrm{MBE})$ or even better $(R, \mathrm{SD})$ than those of the OM ensemble mean over the calibration period (Fig. 5). Looking at its temporal evolution, Fig. 7 (top) reveals a water content that is more underestimated at the beginning of the evaluation period (until 5 October) than later on, while the overall dynamics are quite good. This behaviour seems to be in the continuity of the underestimated water status which established at the end of the calibration exercise (between 27 August and 9 September). As highlighted previously, Fig. 7 shows two different hydrological regimes corresponding to the two subsets identified in Fig. 4 (1 and 2), with subset 2 clearly presenting better scores than subset 1 (Table 5). This is illustrated by better $R$ ( 0.86 compared to 0.71$)$, MBE $(-0.05$ compared to $\left.-0.16 \mathrm{~m}^{3} \mathrm{~m}^{-3}\right)$ and RMSE values $(0.06 \mathrm{com}-$ pared to $\left.0.16 \mathrm{~m}^{3} \mathrm{~m}^{-3}\right)$, despite a higher SD $\left(0.05 \mathrm{~m}^{3} \mathrm{~m}^{-3}\right)$ than subset 1 and observations $\left(0.02 \mathrm{~m}^{3} \mathrm{~m}^{-3}\right.$ for both $)$. The better scores of subset 2 are explained by a higher porosity of the substrate $\left(0.674\right.$ instead of $0.411 \mathrm{~m}^{3} \mathrm{~m}^{-3}$ for subset 1 ), which is the only different hydrological characteristic between the two subsets. Indeed, the subset 2 higher porosity allows for a higher water content to be reached within the substrate matrix when it is saturated.

The better scores of subset 2 for simulating the water content of the substrate logically provides better scores as well for simulating the amount of water discharged at the base of the green roof, with a much better PBE $(61 \%$ against $192 \%$ for subset 1) and similar RMSEs (0.07 and $0.06 \mathrm{~m}^{3}$ day $\left.^{-1}\right)$ despite a weaker correlation (0.66 against 0.83$)$. Overall, evaluation scores for the drainage are acceptable and generally better than those over the calibration period even if the model overestimates the drainage most of the time. As mentioned previously, the background drainage always simulated by the model explains a large part of the error on the accumulated drainage, i.e. 1.2 and $0.5 \mathrm{~m}^{3}$ for subsets 1 and 2, respectively, over the evaluation period (for cumulated bias errors of 4.2 and $2.3 \mathrm{~m}^{3}$, respectively). 

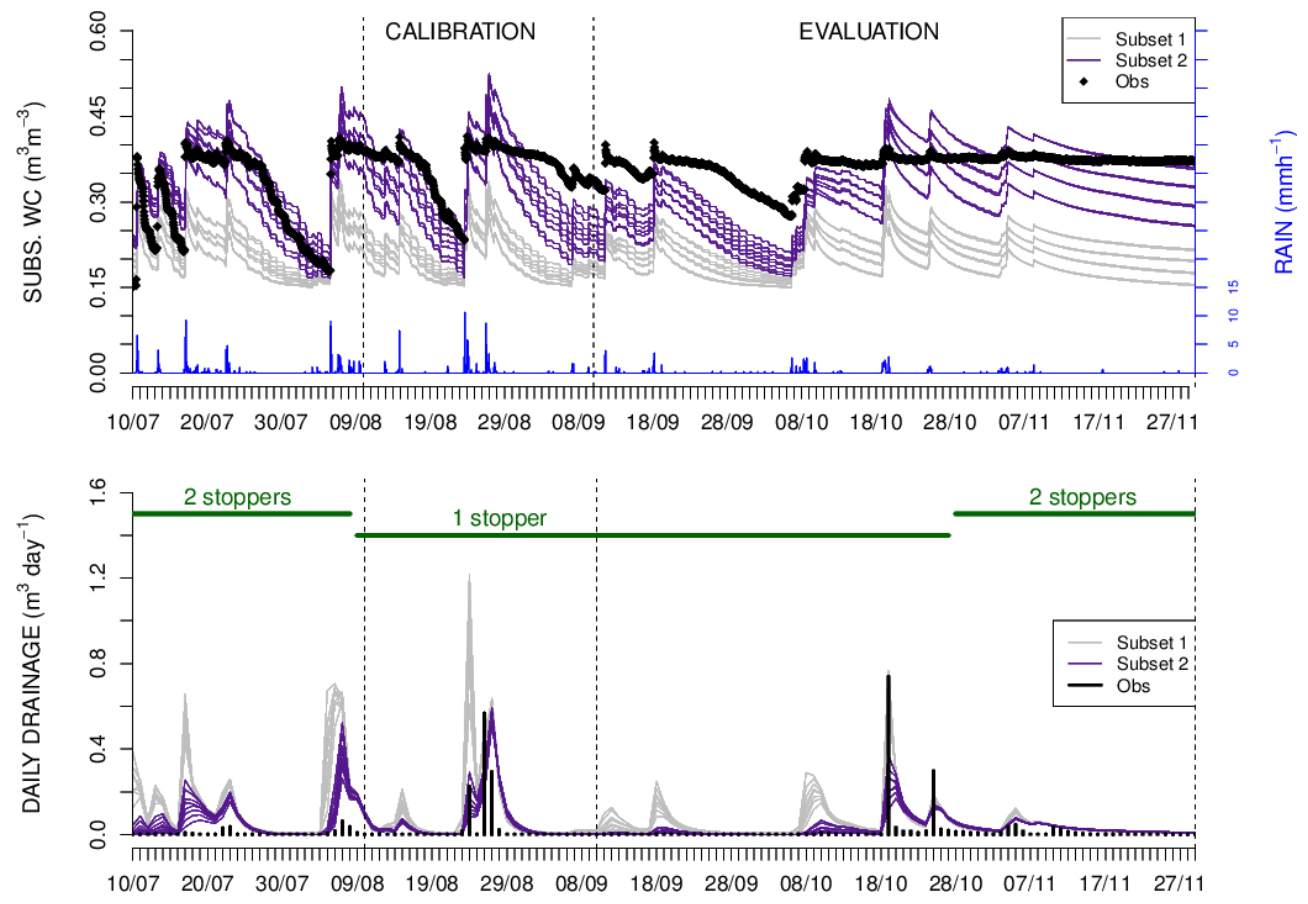

Fig. 7. Evolution between 10 July 2011 and 29 November 2011 of SUBSTRATE water content (top) and daily outlet DRAINAGE (bottom), as observed and simulated by the GREENROOF OM ensemble. Rain amount recorded during the experiment is represented by blue bars (right-hand-side axis on top graph).

Table 5. Statistical scores for the simulations of the OM ensemble over the evaluation time period ( $R$ the correlation coefficient, RMSE the root-mean-square error, MBE the mean bias error, PBE the mean bias error expressed in percentages, CBE the bias error estimated on the variable accumulated over the period, and SD the standard deviation). Score units depend on the variable analysed.

\begin{tabular}{|c|c|c|c|c|c|c|c|c|c|c|c|c|c|c|c|c|}
\hline \multirow[b]{2}{*}{ SCORES } & \multicolumn{4}{|c|}{ SUBS. WATER CONTENT } & \multicolumn{4}{|c|}{ OUTLET DRAINAGE } & \multicolumn{4}{|c|}{ SUBS. TEMPERATURE } & \multicolumn{4}{|c|}{ DRAIN. LAYER TEMPERATURE } \\
\hline & $R$ & RMSE & MBE & SD & $R$ & RMSE & PBE & $\mathrm{CBE}$ & $R$ & RMSE & MBE & SD & $R$ & RMSE & MBE & SD \\
\hline UNIT & - & & $\mathrm{m}^{3} \mathrm{~m}^{-3}$ & & - & $\mathrm{m}^{3}$ day $^{-1}$ & $\%$ & $\mathrm{~m}^{3}$ & - & & ${ }^{\circ} \mathrm{C}$ & & - & & ${ }^{\circ} \mathrm{C}$ & \\
\hline OM mean & 0.86 & 0.11 & -0.10 & 0.04 & 0.81 & 0.06 & 127 & 3.3 & 0.91 & 4.32 & 2.68 & 6.92 & 0.89 & 3.69 & 1.10 & 6.73 \\
\hline $\mathrm{OM} \min$ & 0.50 & 0.04 & -0.01 & 0.02 & 0.48 & 0.05 & 32 & 1.9 & 0.88 & 3.59 & 2.25 & 6.35 & 0.85 & 2.90 & 0.69 & 6.16 \\
\hline OM max & 0.87 & 0.18 & -0.18 & 0.06 & 0.88 & 0.08 & 246 & 5.0 & 0.92 & 5.29 & 3.23 & 7.63 & 0.92 & 4.74 & 1.64 & 7.49 \\
\hline S1 mean & 0.71 & 0.16 & -0.16 & 0.02 & 0.83 & 0.06 & 192 & 4.2 & 0.90 & 4.85 & 2.99 & 7.31 & 0.87 & 4.25 & 1.39 & 7.13 \\
\hline S2 mean & 0.86 & 0.06 & -0.05 & 0.05 & 0.66 & 0.07 & 61 & 2.3 & 0.92 & 3.81 & 2.37 & 6.53 & 0.91 & 3.15 & 0.81 & 6.36 \\
\hline OBS & & & & 0.02 & & & & & & & & 4.54 & & & & 4.25 \\
\hline
\end{tabular}

\subsubsection{Thermal performance}

The evolution of recorded and simulated green roof temperatures is presented in Fig. 8. Whether at the bottom of the substrate (at $96 \mathrm{~mm}$ ) or the drainage layer (at $148 \mathrm{~mm}$ ), the temperatures estimated by GREENROOF demonstrate a good correlation with those observed (respectively 0.91 and 0.89 for the OM ensemble mean, Table 5). By contrast, even if the model is able to capture seasonal variations, the temperatures simulated by GREENROOF as well as their daily amplitudes are greater than that observed. This corresponds to an MBE of 2.68 and $1.10^{\circ} \mathrm{C}$ for the substrate and the drainage layers, respectively, and an RMSE of 4.32 and $3.69^{\circ} \mathrm{C}$. This overestimation of soil temperature is coherent with the underestimation of water content in the substrate layer since the effective thermal properties of the soil matrix are calculated according to Peters-Lidard et al. (1998) based on the dry thermal properties shown in Table 3, as well as the porosity and the water content of the soil matrix. Eventually, an underestimated water content will generate lower thermal conductivity and heat capacity than in reality, with a consequent increase in the soil matrix temperature. This impact has been evaluated on one of the best OM simulations by forcing the effective thermal characteristics of the substrate to those that it would have at field capacity: depending on the substrate moisture status in the initial simulation, this effect only contributes to a cooling in temperatures of 0.5 to $1.5^{\circ} \mathrm{C}$. This implies that other processes might be responsible for the temperature bias and the higher amplitudes of the temperature 

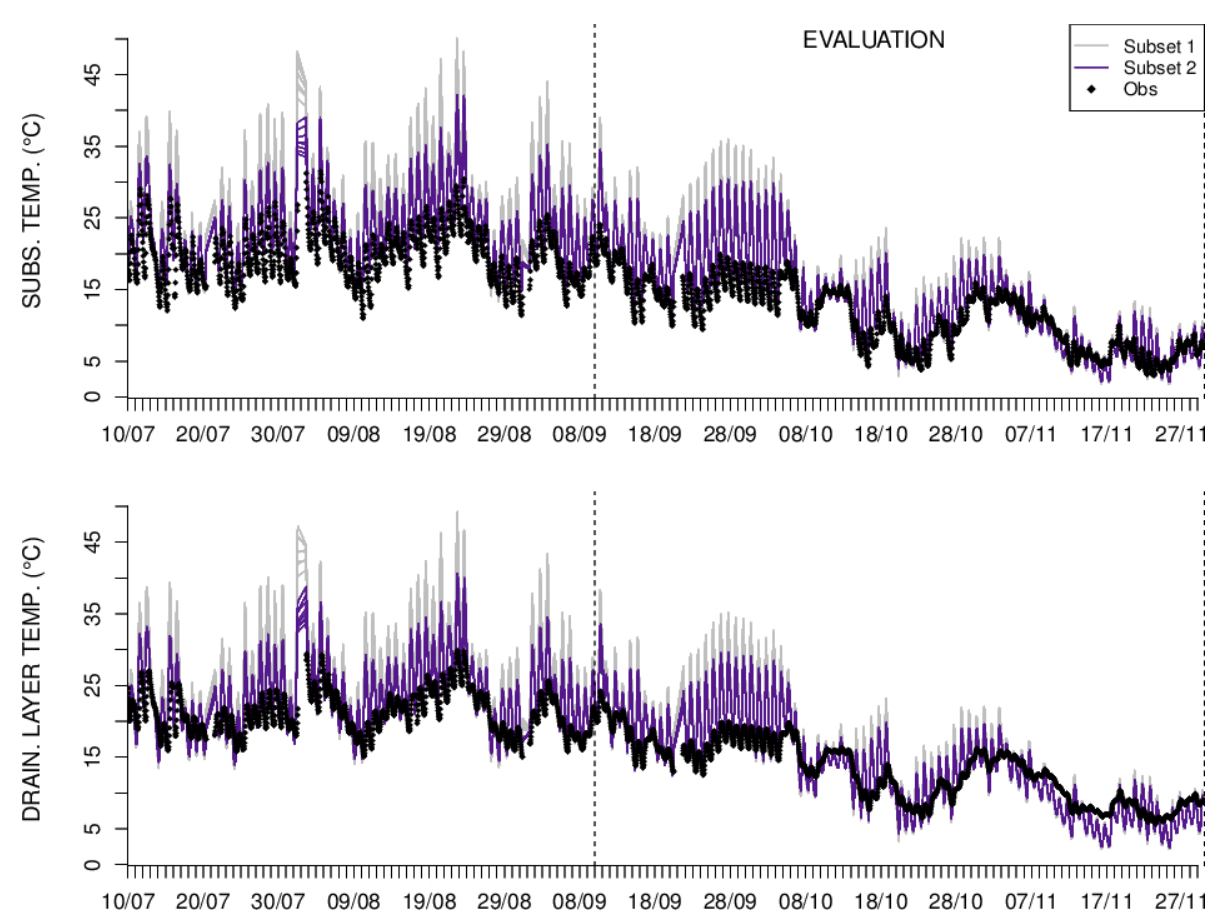

Fig. 8. Evolution between 10 July 2011 and 29 November 2011 of SUBSTRATE (top) and DRAINAGE layer (bottom) temperatures, as observed and simulated by the GREENROOF OM ensemble.

simulated in the substrate. It may originate directly from the initialization of the dry thermal characteristics themselves or from the simulation of the surface energy fluxes. So far, the analysis of the amplitude and the partitioning of simulated sensible and latent heat flux does not highlight any incoherence with the meteorological forcings experienced by the green roof, but another case study with longer time series and surface flux data would be needed to study these aspects and improve the model. Finally, as expected by its better performance in modelling substrate water content, the OM subset 2 performs slightly better at simulating substrate temperatures than subset 1, as shown by Fig. 8 and Table 5, with better RMSE and MBE values than subset 1 . This results in better temperature scores for the subset 2 in the drainage layer. Eventually the analysis of the two OM subsets suggests that a porosity of 0.674 instead of $0.411 \mathrm{~m}^{3} \mathrm{~m}^{-3}$ for the substrate is a more appropriate value for modelling this case study plot with GREENROOF.

\section{Conclusions and perspectives}

A parameterization called GREENROOF for simulating extensive green roofs across the cities has been developed within TEB, which is consistent with the modular architecture of SURFEX. While the natural surface scheme ISBADF simulates the transfers of heat and water within the natural compartments of the green roof, TEB handles transfers within artificial layers of the green roof and the structural roof. The GREENROOF module consists of the two-way coupling of these two models via the heat flux which establishes between the natural and artificial roof layers in contact and their respective temperatures. A vertical green roof design as well as two greening options (grass or sedum lawn) are available. GREENROOF is evaluated for a case study an experimental green roof plot located in the northeast of France. Initially, a calibration exercise is realized in order to identify the soil type that best describes the hydrological behaviour of the soil-forming materials used for the drainage layer of the green roof plot. Calibration results show that the hydrological behaviour of expanded clay granules is closest to the behaviour of peat, which is an important indication for the modelling community as drainage layers are not generally simulated by existing green roof models. After calibration, results show that GREENROOF performs well in reproducing the dynamics of both the outlet drainage and the water content within the substrate, with a tendency to overestimate drainage and underestimate water content. The differences between modelled and observed water contents do not impact too much the simulation of temperatures, which presents satisfactory statistical scores. Nonetheless, on this case study plot, GREENROOF tends to overestimate soil temperatures and their amplitudes. Due to the thermal inertia of the soil layers, the temperature of the drainage layer is the least biased, which allows for a good thermal coupling with the artificial/structural roof layers. Considering the results of this study, the future developments of GREENROOF should 
include the analysis of experimental green roof plots, providing complete records including surface flux data, as well as plots with a retention layer instead of a drainage layer.

Since the experimental plot studied (extensive, sedum lawn, typical substrate and drainage layer materials) is a type of green roof that is frequently implemented on urban buildings, the hydrological characteristics highlighted via this case study are retained to simulate green roofs at the scale of cities. Thanks to the coupled developments of the GREENROOF module and the building energy model (BEM, Bueno et al., 2012) within TEB, impact studies are currently in progress to assess the potential of green roofs (and associated water resources) as a sustainable adaptation strategy for cities in terms of indoor thermal comfort and energy consumption, as well as urban heat island mitigation if coupled to an atmospheric model. Also, through the various options currently available in ISBA, other impacts of green roofs could be studied at the scale of cities, such as, for example, their potential for carbon dioxide sequestration.

\section{Code availability}

The GREENROOF module has been implemented within the version 7.3 of the SURFEX platform. For further details, including how to obtain a copy of the source code, see http://www.cnrm.meteo.fr/surfex/.

\section{Appendix A}

\section{Fitting $b$ coefficient of the water retention curve} to observations

\section{A1 Method}

The $b$ coefficient is involved in a formulation implemented in ISBA (hence called the GREENROOF module) which connects the water potential to the water content in a soil matrix derived by Clapp and Hornberger (1978):

$$
\frac{\psi}{\psi_{\mathrm{SAT}}}=\left(\frac{\mathrm{wc}}{\mathrm{wc}_{\mathrm{SAT}}}\right)^{-b}
$$

where $\psi(\mathrm{m})$ is the water potential for a specific water content $\mathrm{wc}\left(\mathrm{m}^{3} \mathrm{~m}^{-3}\right), \psi_{\mathrm{SAT}}(\mathrm{m})$ is the water potential at saturation corresponding to the water content at saturation (i.e. the porosity) $\mathrm{wcSAT}_{\mathrm{SAT}}\left(\mathrm{m}^{3} \mathrm{~m}^{-3}\right)$, and $b$ is an empirical coefficient, which must be estimated. This formulation when plotted for a soil is called the water retention curve. Following Eq. (A1), the $b$ coefficient can be estimated, if observations are available, as the opposite of the slope of the water retention curve expressed as

$\operatorname{LOG}_{10}\left(\frac{\psi}{\psi_{\mathrm{SAT}}}\right)=-b \times \mathrm{LOG}_{10}\left(\frac{\mathrm{wc}}{\mathrm{wc}_{\mathrm{SAT}}}\right)$.

Note that for applications of ISBA to natural soils, the $b$ coefficient does not need to be user-calibrated because it

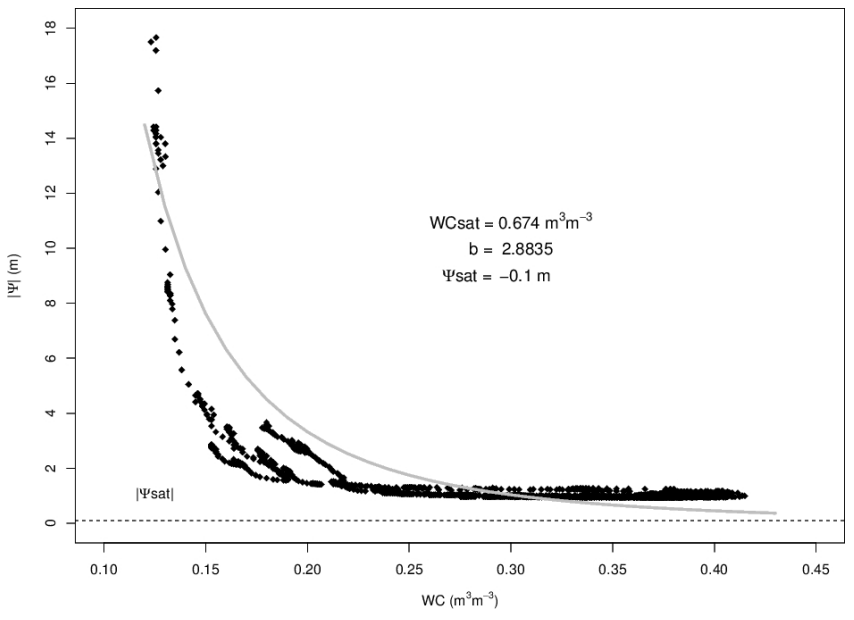

Fig. A1. Fit of water retention curve coefficient and matrix potential at saturation to observations when porosity $=0.674 \mathrm{~m}^{3} \mathrm{~m}^{-3}$.

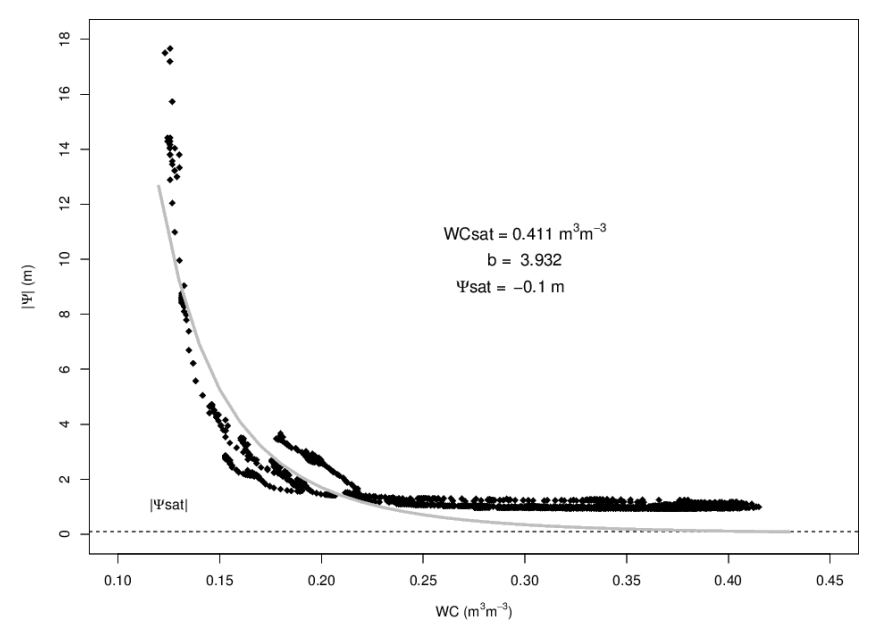

Fig. A2. Fit of water retention curve coefficient and matrix potential at saturation to observations when porosity $=0.411 \mathrm{~m}^{3} \mathrm{~m}^{-3}$.

is estimated within the model after pedotransfer functions based on user-input soil texture (sand and clay fractions). The case of green roof soil-forming materials is different because sand and clay fractions are not really appropriate to characterize them. Hence, for the substrate of the green roof studied for which water contents and matrix potentials were recorded between July and November 2011, the $b$ coefficient can be estimated.

\section{A2 Fitting $b$ coefficients for the case study green roof substrate}

The $b$ coefficient has been estimated based on Eq. (A2) using a linear regression for two compatible combinations of porosity and saturated water potential tested in the calibration exercise, respectively $0.674 \mathrm{~m}^{3} \mathrm{~m}^{-3}$ with $-0.1 \mathrm{~m}$ for the first combination and $0.411 \mathrm{~m}^{3} \mathrm{~m}^{-3}$ with $-0.1 \mathrm{~m}$ for the second 
combination. For the first combination, the linear regression resulted in a fitted $b$ coefficient of 2.9. The same treatment for the second combination (Fig. A2) resulted in a fitted $b$ coefficient of 3.9. The two resulting water retention curves are displayed in Figs. A1 and A2, showing the agreements between the $b$ fitted theoretical curves and the observed curves. For both combinations, the agreement is acceptable, but the Clapp and Hornberger (1978) formulation does not seem able to reproduce the tail of the observed water retention curve - when water content is above $0.20 / 0.25 \mathrm{~m}^{3} \mathrm{~m}^{-3}$. Also, the second combination appears better than the first at reproducing the inflexion of the observed curve, although it does not capture the points with the lowest water contents/greatest matrix potentials. However, the functioning of water potential probes can be well altered in dry conditions because of the rough texture (and the resulting lack of contact) of the soil-forming material of the green roof substrate. This may question the validity of the high water potential recorded on that green roof plot.

Acknowledgements. The results presented in this publication are the outcome of two research projects: MUSCADE (Modélisation Urbaine et Stratégie d'adaptation au Changement climatique pour Anticiper la Demande et la production Énergétique, ANR-09VILL-0003) and VegDUD (Rôle du végétal dans le Développement Urbain Durable, ANR-09-VILL-0007). We are grateful for the expertise and support provided by Aaron Boone and Bertrand Decharme (CNRM-GAME) on the ISBA-DF model.

Edited by: D. Lunt

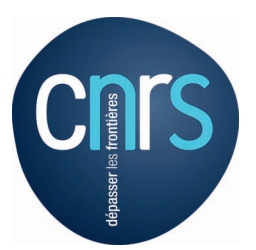

The publication of this article is financed by CNRS-INSU.

\section{References}

ACERMI [Association pour la CERtification des Matériaux Isolants: CSTB-LNE]: CERTIFICAT ACERMI No. 04/003/323, Licence no. 04/003/323, 2009.

Alexandri, E. and Jones, P.: Developing a one-dimensional heat and mass transfer algorithm for describing the effect of green roofs on the built environment: Comparison with experimental results, Build. Environ., 42, 2835-2849, doi:10.1016/j.buildenv.2006.07.004, 2007.

ARGEX: available at: http://www.argex.eu/en/products/ characteristics.html (last access: 24 February 2012), 2012.

Bass, B. and Baskaran, B.: Evaluating Rooftop and Vertical Gardens as an Adaptation Strategy for Urban Areas, Report no NRCC46737, Edited by National Research Council Canada, Institute for Research in Construction, Ottawa (Canada), 2003.

Bass, B., Krayenhoff, E. S., Martilli, A., Stull, R. B., and Auld, H.: The impact of green roofs on Toronto's urban heat island, in: Proceedings of the First North American Green Roof Conference: Greening Rooftops for Sustainable Communities, 2030 May, Chicago, Toronto (Canada), Cardinal Group, 292-304, 2003.

Berghage, R., Beattie, D., Jarrett, A., Thuring, C., and Razaei, F.: Green Roofs for Stormwater Runoff Control, Report no EPA/600/R-09/026, February 2009, edited by: the National Risk Management Research Laboratory, Office of Research and Development, US Environment Protection, Agency, Cincinnati, OH 45268, 2009.

Berndtsson, J. C., Bengtsson, L., and Jinno, K.: Runoff water quality from intensive and extensive vegetated roofs, Ecol. Eng., 35, 369-380, 2009.

BING [Federation of European Rigid Polyurethane Foam Associations]: Thermal insulation materials made of rigid polyurethane foam (PUR/PIR), Properties - Manufacture, Report no 1, 6 October, 2006, available at: http://www.excellence-in-insulation.eu/ site/fileadmin/user_upload/PDF/Thermal_insulation_materials_ made_of_rigid_polyurethane_foam.pdf, last access: 27 October 2013 .

Boone, A.: Modélisation des processus hydrologiques dans le schéma de surface ISBA: Inclusion d'un reservoir hydrologique, du gel et modélisation de la neige, $\mathrm{PhD}$ thesis, Université Paul Sabatier, Toulouse, France, 2000.

Boone, A., Masson, V., Meyers, T., and Noilhan, J.: The influence of the inclusion of soil freezing on simulations by a soil-vegetationatmosphere transfer scheme, J. Appl. Meteorol., 39, 1544-1569, 2000.

Bouzouidja, R.: Caractérisation du substrat d'une toiture végétalisée, Master's thesis, University of Lorraine, Nancy, France, 2010.

Bouzouidja, R., Lacroix, D., Séré, G. and Claverie, R.: Experimental determination of hydrological parameters of green roofs, Build. Environ., in preparation, 2012.

Bueno, B., Pigeon, G., Norford, L. K., Zibouche, K., and Marchadier, C.: Development and evaluation of a building energy model integrated in the TEB scheme, Geosci. Model Dev., 5, 433-448, doi:10.5194/gmd-5-433-2012, 2012.

Carter, T. and Butler, C.: Ecological impacts of replacing traditional roofs with green roofs in two urban areas, Cities Environ., 1, 117, 2008.

Castleton, H. F., Stovin, V., Beck, S. B. M., and Davison, J. B.: Green roofs; building energy savings and the potential for retrofit, Energ. Buildings, 41, 1582-1591, 2010.

Clapp, R. B. and Hornberger, G. M.: Empirical equations for some soil hydraulic properties, Water Resour. Res., 14, 601-604, 1978.

CRITT Horticole [Centre régional pour l'Innovation et le Transfert Technologique Horticole]: Définition et mesure du LAI, Intégration de la résistance stomatique (RS) dans la formule de l'ETP, Unpublished report, 2012.

Decharme, B., Boone, A., Delire, C., and Noilhan, J.: Local evaluation of the Interaction between Soil Biosphere Atmosphere soil multilayer scheme using four pedotransfer functions, J. Geophys. Res., 116, D20126, doi:10.1029/2011JD016002, 2011.

Del Barrio, E. P.: Analysis of the green roofs cooling potential in buildings, Energ. Buildings, 27, 179-193, 1998.

de Munck, C., Pigeon, G., Masson, V., Meunier, F., Bousquet, P., Tréméac, B., Merchat, M., Poeuf, P., and Marchadier, C.: How much air conditioning can increase air temperatures for 
a city like Paris (France)?, Int. J. Climatol., 33, 210-227, doi:10.1002/joc.3415, 2013.

Diak, G. R., Bland, W. L., Mecikalski, J. R., and Anderson, M. C.: Satellite-based estimates of longwave radiation for agricultural applications, Agr. Forest Meteorol., 103, 349-355, doi:10.1016/S0168-1923(00)00141-6, 2000.

Doya, M., Briottet, X., Djedjig, R., and Ouldboukhitine, S.: Description des mesures VEGDUD du 23/09/2011, Unpublished report, 2011.

Durham, A. K., Rowe, D. B., and Rugh, C. L.: Effect of watering regimen on chlorophyll fluorescence and growth of selected green roof plant taxa, HortScience, 41, 1623-1628, 2006.

EEA: European Environment Agency: Urban adaptation to climate change in Europe, Challenges and opportunities for cities together with supportive national and European policies, EEA Report no 2/2012, ISSN 1725-9177, 2012.

Falienor: Résultats de l'analyse de substrat de toiture végétalisée No 1807676 - 14-F TOITURE par le Laboratoire SAS, Issued on $09 / 03 / 2010,2010$.

Farouki, O. T.: Thermal properties of soils, Ser. on Rock and Soil Mech., 11, 136 pp., Trans. Tech. Publ., Clausthal-Zellerfled, Germany, 1986.

Feng, C., Meng, Q., and Zhang, Y.: Theoretical and experimental analysis of the energy balance of extensive green roofs, Energ. Buildings, 42, 959-965, 2010.

Foster, J., Lowe, A., and Winkelman, S.: The value of green infrastructure for urban climate adaptation, Published by the Center for Clean Air Policy, Washington DC, USA, February 2011, 2011.

Getter, K. L. and Rowe, D. B.: The role of extensive green roofs in sustainable development, HortScience, 41, 1276-1285, 2006.

Giguère, M.: Mesures de lutte aux îlots de chaleur urbains. Revue de literature, Direction des risques biologiques, environnementaux et occupationnels, Institut National de Santé Publique, Gouvernement du Québec, Juillet 2009, 2009.

Gill, S. E., Handley, J. F., Ennos, A. R., and Pauleit, S.: Adapting cities for climate change: the role of the green infrastructure, Built Environ., 33, 115-133, 2007.

Hamdi, R. and Masson, V.: Inclusion of a Drag Approach in the Town Energy Balance (TEB) Scheme: Offline 1D Evaluation in a Street Canyon, J. Appl. Meteorol. Clim., 47, 2627-2644, doi:10.1175/2008JAMC1865.1, 2008.

Hilten, R. N., Lawrence, T. M., and Tollner, E. W.: Modeling stormwater runoff from green roofs with HYDRUS-1D, J. Hydrol., 358, 288-293, 2008.

Jacquet, S.: Performance énergétique d'une toiture végétale au centre-ville de Montréalm Résumé de mémoire, Centre d'Ecologie Urbaine de Montréal, ISBN 978-2-9810129-8-2., available at: http://www.ecologieurbaine.net/node/1214, 2011.

Jaffal, I., Ould-Boukhitine, S.-E., and Belarbi, R.: A comprehensive study of the impact of green roofs on building energy performance, Renew. Energ., 43, 157-164, 2012.

Jarvis, P.: The interpretation of the variations in leaf water potential and stomatal conductance found in canopies in the field, Philosophical Transactions of the Royal Society of London, Biol. Sci., 273, 593-610, 1976.

Jim, C. Y.: Effect of vegetation biomass structure on thermal performance of tropical green roof, Landscape Ecol. Eng., 8, 173-187, doi:10.1007/s11355-011-0161-4, 2011.
Jim, C. Y. and He, H.: Coupling dynamics with meteorological conditions in the green roof ecosystem, Ecol. Eng., 36, 1052-1063, 2010.

Jim, C. Y. and Peng, L. L. H.: Weather effect on thermal and energy performance of an extensive tropical green roof, Urban For. Urban Gree., 11, 73-85, 2011.

Jim, C. Y. and Tsang, S. W.: Modeling the heat diffusion process in the abiotic layers of green roofs, Energ. Buildings, 43, 13411350, 2011.

Kalzip $^{\circledR}$ : Kalzip low U-value roof system - achieving $0.10 \mathrm{~W} / \mathrm{m} 2 / \mathrm{K}$, Product review, 2010, available at: http: //www.kalzip.com/PDF/uk/Kalzip-low-U-value-system.pdf, last access: 27 October 2013.

Kumar, R. A. and Kaushik, S. C.: Performance evaluation of green roof and shading for thermal protection of buildings, Build. Environ., 40, 1505-1511, 2005.

Lawlor, G., Currie, B. A., Doshi, H., and Wieditz, I.: Green roofs: a resource manual for municipal policy makers, Report 65255 , Published by Canada Mortgage and Housing Corporation, May 2006, 2006.

Lawrence, D. M. and Slater, A. G.: Incorporating organic soil into a global climate model, Clim. Dynam., 30, 145-160, 2008.

Lazzarin, R. M., Castellotti, F., and Busato, F.: Experimental measurements and numerical modelling of a green roof, Energ. Buildings, 37, 1260-1267, 2005.

Leca ${ }^{\circledR}$ : Declaration of technical specifications BS EN 13055-1 for lightweight aggregate, Issued on 01-01-2009, 2009.

Leca ${ }^{\circledR}$ : available at: http://www.leca.co.uk/33755 (last access: 24 February 2012), 2012.

Lemonsu, A. and Masson, V.: Simulation of a summer urban breeze over Paris, Bound.-Lay. Meteorol., 104, 463-490, 2002.

Lemonsu, A., Grimmond, C. S. B., and Masson, V.: Modeling the surface energy balance of the core of an old Mediterranean city: Marseille, J. Appl. Meteorol., 43, 312-327, 2004.

Lemonsu, A., Bélair, S., Mailhot, J., and Leroyer, S.: Evaluation of the Town Energy Balance Model in Cold and Snowy Conditions during the Montreal Urban Snow Experiment 2005, J. Appl. Meteorol. Climatol., 49, 346-362, 2010.

Lemonsu, A., Pigeon, G., Marchadier, C., and Salagnac, J.-L.: Research report for the VURCA project, Scénarios du bâti \& simulations, No ANR-08-VULCN-013 VURCA, 47 pp., 2011.

Lemonsu, A., Masson, V., Shashua-Bar, L., Erell, E., and Pearlmutter, D.: Inclusion of vegetation in the Town Energy Balance model for modelling urban green areas, Geosci. Model Dev., 5, 1377-1393, doi:10.5194/gmd-5-1377-2012, 2012.

Masson, V.: A physically-based scheme for the urban energy budget in atmospheric models, Bound.-Lay. Meteorol., 94, 357-397, 2000.

Masson, V., Champeaux, J. L., Chauvin, F., Meriguet, C., and Pigeon, G.: ECOCLIMAP: a global database of land surface parameters at $1-\mathrm{km}$ resolution in meteorological and climate models, J. Climate, 16, 1261-1282, 2003.

Masson, V., Le Moigne, P., Martin, E., Faroux, S., Alias, A., Alkama, R., Belamari, S., Barbu, A., Boone, A., Bouyssel, F., Brousseau, P., Brun, E., Calvet, J.-C., Carrer, D., Decharme, B., Delire, C., Donier, S., Essaouini, K., Gibelin, A.-L., Giordani, H., Habets, F., Jidane, M., Kerdraon, G., Kourzeneva, E., Lafaysse, M., Lafont, S., Lebeaupin Brossier, C., Lemonsu, A., Mahfouf, J.-F., Marguinaud, P., Mokhtari, M., Morin, S., Pigeon, G., Sal- 
gado, R., Seity, Y., Taillefer, F., Tanguy, G., Tulet, P., Vincendon, B., Vionnet, V., and Voldoire, A.: The SURFEXv7.2 land and ocean surface platform for coupled or offline simulation of earth surface variables and fluxes, Geosci. Model Dev., 6, 929-960, doi:10.5194/gmd-6-929-2013, 2013.

Mentens, J., Raes, D., and Hermy, M.: Green roofs as a tool for solving the rainwater runoff problem in the urbanized 21 st century?, Landscape Urban Plan., 77, 217-226, 2006.

Mualem, Y.: A new model to predicting the hydraulic conductivity of unsaturated porous media, Water Resour. Res., 12, 513-522, 1976.

Nardini, A., Andri, S., and Crasso, M.: Influence of substrate depth and vegetation type on temperature and water runoff mitigation by extensive green roofs: shrubs versus herbaceous plants, Urban Ecosyst., 15, 697-708, doi:10.1007/s11252-011-0220-5, 2012.

Noilhan, J. and Planton, S.: A simple parameterization for land surface processes for meteorological models, Mon. Weather Rev., 117, 536-549, 1989.

Oberndorfer, E., Lundholm, J., Bass, B., Coffman, R. R., Doshi, H., Dunnett, N., Gaffin, S., Kohler, M., Liu, K. K. Y., and Rowe, B.: Green Roofs as Urban Ecosystems: Ecological Structures, Functions, and Services, BioScience, 57, 823-833, 2007.

Ochs, F., Heidemann, W., and Müller-Steinhagen, H.: Effective thermal conductivity of the insulation of high temperature underground thermal stores during operation, in: Proceedings of the Ecostock 2006 conference, Richard Stockton College, New Jersey, USA, 31 May-2 June 2006, 2006.

Offerle, B., Grimmond, C. S. B., and Fortuniak, K.: Heat storage and anthropogenic heat flux in relation to the energy balance of a central European city centre, Int. J. Climatol., 25, 1405-1419, 2005.

Ouldboukhitine, S.-E., Belarbi, R., Jaffal, I., and Trabelsi, A.: Assessment of green roof thermal behaviour: a couple heat and mass transfer model, Build. Environ., 46, 2624-2631, doi:10.1016/j.buildenv.2011.06.021, 2011.

Palla, A., Gnecco, I., and Lanza, G.: Unsaturated 2D modelling of subsurface water flow in the coarse-grained porous matrix of a green roof, J. Hydrol., 379, 193-204, 2009.

Palla, A., Gnecco, I., and Lanza, G.: Compared performance of a conceptual and a mechanistic hydrologic models of a green roof, Hydrol. Process., 26, 73-84, 2012.

Penney, J.: Climate change adaptation in the city of Toronto. Lessons for Great Lakes communities. Clean Air Partnership, Toronto, Ontario, Canada, December 2008, available at: http://www.cleanairpartnership.org/files/Climate\%20Change\% 20Adaptation $\% 20$ in $\% 20$ the $\% 20$ City $\% 20$ of\%20Toronto $\% 20-\%$ 20Lessons\%20for\%20Great\%20Lakes\%20Communities\% 20\%28Penney,\%20J.\%202008\%29.pdf (last access: 27 October 2013), 2008.

Peters-Lidard, C. D., Blackburn, E., Lian, X., and Wood, E. F.: The effect of soil thermal conductivity parameterization on surface energy fluxes and temperatures, J. Atmos. Sci., 55, 1209-1224, doi:10.1175/1520-0469(1998)055<1209:TEOSTC>2.0.CO;2, 1998.

Pigeon, G., Moscicki, M. A., Voogt, J. A., and Masson, V.: Simulation of fall and winter surface energy balance over a dense urban area using the TEB scheme, Meteorol. Atmos. Phys., 102, 159-172, 2008.
Prata, A. J.: A new long-wave formula for estimating downward clear-sky radiation at the Surface, Q. J. R. Meteorol. Soc., 122, 1127-1151, 1996.

RECTICEL ${ }^{\circledR}:$ available at: http://www.recticelinsulation.fr/ nos-produits/powerline/\#donnees_techniques (last access: 1 June 2012), 2012.

Rosenzweig, C., Solecki, W. D., Parshall, L., Lynn, B., Cox, J., Goldberg, R., Hodges, S., Gaffin, S., Slosberg, R. B., Savio, P., Dunstan, F., and Watson, M.: Mitigating New York City's Heat Island. Integrating Stakeholder Perspectives and Scientific Evaluation, B. Am. Meteorol. Soc., 90, 1297-1312, 2009.

Sailor, D. J.: A green roof model for building energy simulation programs, Energ. Buildings, 40, 1466-1478, 2008.

SILRES ${ }^{\circledR}$ : available at: www.wacker.com/cms/media/publications/ downloads/6528_EN.pdf (last access: 24 February 2012), 2012.

Simunek, J., Voel, T., and Van Genuchten, M. Th.: The SWMS_2D code for simulating water flow and solute transport on twodimensional variably saturated media, Version 1.21., Research report No 132, US Salinity Laboratory, USDA, ARS, Riverside, California, 197 pp., 1994.

Simunkek, J., Van Genuchten, M. Th., and Sejna, M.: The HYDRUS_1D Software package for simulating the one-dimensional movement of water, heat and multiple solutes in variablysaturated media, Version 3.0, HYDRUS Software Series 1. Dept of Environmental Science, University of California Riverside, Riverside, California, USA, 240 pp., 2005.

Sinclair: available at: http://www.william-sinclair.co.uk/industrial/ products/expanded_clay (last access: 24 February 2012), 2012.

SOPREMA $^{\circledR}:$ SOPRALENE ${ }^{\circledR}$ FLAM JARDIN, Fiche technique No DT-10/005_FR CE, 2012a.

SOPREMA $^{\circledR}:$ SOPRALENE ${ }^{\circledR}$ FLAM 180, Fiche technique No DT-09/086_FR CE, 2012b.

Taylor, K. E.: Summarizing multiple aspects of model performance in a single diagram, J. Geophys. Res., 106, 7183-7192, 2001.

USEPA: Reducing Urban Heat Islands: Compendium of Strategies, Green Roofs, 26 pp., available at: http://www.epa.gov/hiri/ mitigation/greenroofs.htm, 2008.

Van Genuchten, M. Th.: A closed-form equation for predicting the hydraulic conductivity of unsaturated soils, Soil Sci. Soc. Am. J., 44, 892-898, 1980.

Van Woert, N. D., Rowe, D. B., Andresen, J. A., Rugh, C. L., and Xiao, L.: Watering regime and green roof substrate design affect Sedum plant growth, HortScience, 40, 659-664, 2005.

Voyde, E., Fassman, E., and Simcock, R.: Hydrology of an extensive living roof under sub-tropical climate conditions in Auckland, New Zealand, J. Hydrol., 394, 384-395, 2010.

Wark, C. G. and Wark, W. W.: Green roof specifications and standards. Establishing an emerging technology, The Construction Specifier, 56, August 2003, n0 8, available at: www. proenviroconstruction.com/pdf/GreenRoof.pdf, 2003.

Wolf, D. and Lundholm, J.T.: Water uptake in green roof microcosms: effects of plant species and water availability, Ecol. Eng., 33, 179-186, 2008.

Yu, C. and Zheng, C.: HYDRUS: software for flow and transport modeling in variably saturated media, Ground Water, 48, 787791, 2010. 